\title{
Endocannabinoid-Mediated Long-Term Depression of Afferent Excitatory Synapses in Hippocampal Pyramidal Cells and GABAergic Interneurons
}

\author{
Zoltán Péterfi, ${ }^{1 \star}$ Gabriella M. Urbán, ${ }^{1 \star}$ Orsolya I. Papp, ${ }^{1}$ Beáta Németh, ${ }^{1}$ Hannah Monyer,,${ }^{2}$ Gábor Szabó, ${ }^{1}$ \\ Ferenc Erdélyi, ${ }^{1}$ Ken Mackie, ${ }^{3}$ Tamás F. Freund, ${ }^{1}$ Norbert Hájos, ${ }^{1}$ and István Katona ${ }^{1}$ \\ ${ }^{1}$ Institute of Experimental Medicine, Hungarian Academy of Sciences, H-1083 Budapest, Hungary, ${ }^{2}$ Department of Clinical Neurobiology, University \\ Hospital Heidelberg and German Cancer Research Center (Deutsches Krebsforschungszentrum), 69120 Heidelberg, Germany, and ${ }^{3}$ Department of \\ Psychological and Brain Sciences and Gill Center, Indiana University, Bloomington, Indiana 47405
}

\begin{abstract}
Although endocannabinoids have emerged as essential retrograde messengers in several forms of synaptic plasticity, it remains controversial whether they mediate long-term depression (LTD) of glutamatergic synapses onto excitatory and inhibitory neurons in the hippocampus. Here, we show that parvalbumin- and somatostatin/metabotropic glutamate receptor $1_{\mathrm{a}}\left(\mathrm{mGlu}_{\mathrm{la}}\right)$-positive GABAergic interneurons express diacylglycerol lipase- $\alpha$ (DGL- $\alpha$ ), a synthesizing enzyme of the endocannabinoid 2-arachidonoylglycerol (2-AG), albeit at lower levels than principal cells. Moreover, this lipase accumulates postsynaptically around afferent excitatory synapses in all three cell types. To address the role of retrograde 2-AG signaling in LTD, we investigated two forms: (1) produced by postsynaptic spiking paired with subsequent presynaptic stimulation or (2) induced by group I mGlu activation by (S)-3,5-dihydroxyphenylglycine (DHPG). Neither form of LTD was evoked in the presence of the mGlu ${ }_{5}$ antagonist MPEP [2-methyl-6-(phenylethynyl)-pyridine], the DGL inhibitor THL [N-formyl-L-leucine (1S)-1-[[(2S,3S)-3-hexyl-4oxo-2-oxetanyl]methyl]dodecyl ester], or the intracellularly applied $\mathrm{Ca}^{2+}$ chelator BAPTA in CA1 pyramidal cells, fast-spiking interneurons (representing parvalbumin-containing cells) and interneurons projecting to stratum lacunosum-moleculare (representing somatostatin/ $\mathrm{mGlu}_{1 \mathrm{a}}$-expressing interneurons). Both forms of LTD were completely absent in $\mathrm{CB}_{1}$ cannabinoid receptor knock-out mice, whereas pharmacological blockade of $\mathrm{CB}_{1}$ led to inconsistent results. Notably, in accordance with their lower DGL- $\alpha$ level, a higher stimulation frequency or higher DHPG concentration was required for LTD induction in interneurons compared with pyramidal cells. These findings demonstrate that hippocampal principal cells and interneurons produce endocannabinoids to mediate LTD in a qualitatively similar, but quantitatively different manner. The shifted induction threshold implies that endocannabinoid-LTD contributes to cortical information processing during distinct network activity patterns in a cell type-specific manner.
\end{abstract}

\section{Introduction}

Morphological and functional diversity of cortical GABAergic interneurons along with the unexpected scale of heterogeneity

Received April 5, 2012; revised Aug. 22, 2012; accepted Aug. 25, 2012.

Author contributions: T.F.F., N.H., and I.K. designed research; Z.P., G.M.U., 0.I.P., and B.N. performed research; H.M., G.S., F.E., and K.M. contributed unpublished reagents/analytic tools; Z.P., N.H., and I.K. analyzed data; N.H. and I.K. wrote the paper.

This work was supported primarily by European Research Council Grant 243153 and partly by Hungarian Scientific Research Fund-Norwegian Financial Mechanism Joint Program Grant NNF 78918 (I.K.); by the Wellcome Trust International Senior Research Fellowship (I.K., N.H.); by National Office for Research and Technology Grant OMFB01678/2009 (N.H.); by Bundesministerium für Bildung und Forschung Grant 01GQ1003A (H.M.); and by National Research and Technology Foundation Grant NKTH-OTKA CNK 77793, NIH Grant DA09158 (T.F.F.), and NIH Grants DA009158, DA0216969, and DA011322 (K.M.). We are grateful to Prof. Andreas Zimmer, Dr. Tamás Görcs, Prof. István Mody, and Prof. Zoltán Nusser for generously providing the $\mathrm{CB}_{1}$ receptor knock-out mouse line, the antibody against $\mathrm{mGlu}_{1 \mathrm{a}}$, the Evan software, and the Stimulog software, respectively. We are also indebted to Erzsébet Gregori, Balázs Pintér, and Győző Goda for their excellent technical assistance, and to Dr. Chris Henstridge for critical reading of this manuscript. We also thank László Barna, the Nikon Microscopy Center at Institute of Experimental Medicine, Nikon Austria GmbH, and Auro-Science Consulting, Ltd., for kindly providing microscopy support.

The authors declare no competing financial interests.

*Z.P. and G.M.U. contributed equally to this work.

Correspondence should be addressed to either Dr. Norbert Hájos or Dr. István Katona, Institute of Experimental Medicine, Hungarian Academy of Sciences, Szigony u. 43, H-1083 Budapest, Hungary. E-mail: hajos@koki.hu or katona@koki.hu.

DOI:10.1523/JNEUROSCI.1676-12.2012

Copyright $\odot 2012$ the authors $\quad 0270-6474 / 12 / 3214448-16 \$ 15.00 / 0$ among glutamatergic principal cells is a fundamental feature of cortical circuits (Freund and Buzsáki, 1996; Silberberg et al., 2005; Klausberger and Somogyi, 2008; Varga et al., 2010; Mizuseki et al., 2011). This cellular complexity enables division of labor (Miles et al., 1996), which is reflected in distinctive neuronal outputs during network activity patterns (Klausberger et al., 2003; Gentet et al., 2010). These cell type-specific outputs are predominantly governed by various synaptic conductances that require continuous regulation to follow dynamically changing neuronal ensembles (Buzsáki, 2010; Isaacson and Scanziani, 2011). Numerous forms of synaptic plasticity are manifested in cortical principal cells and interneurons contributing to these "synapsembles" (Feldman, 2009; Buzsáki, 2010; Kullmann and Lamsa, 2011). Long-term depression (LTD) of excitatory synapses is a prime example because it is causally linked to behaviorally relevant processes such as sensory map reorganization (Feldman and Brecht, 2005) or context-dependent spatial learning (Kemp and Manahan-Vaughan, 2007). Among the several mechanistically different forms of LTD, some are dependent primarily on NMDA receptor activation, whereas others also involve group I metabotropic glutamate (mGlu) 
receptors, and may require a retrograde transmitter (Collingridge et al., 2010).

Endocannabinoids, especially 2-arachidonoylglycerol (2AG), have emerged as consensus messengers in retrograde synaptic communication throughout the brain (Alger and Kim, 2011; Katona and Freund, 2012). Diacylglycerol lipase- $\alpha$ (DGL$\alpha$ ), a synthesizing enzyme of $2-\mathrm{AG}$ is also indispensable for all forms of 2-AG-mediated synaptic plasticity studied so far (Gao et al., 2010; Tanimura et al., 2010; Yoshino et al., 2011). Despite its high postsynaptic concentration opposing presynaptic $\mathrm{CB}_{1}$ cannabinoid receptors at excitatory synapses of hippocampal principal cells (Katona et al., 2006; Yoshida et al., 2006), and tight coupling of group I mGlu activation to 2-AG mobilization (Jung et al., 2005), mGlu-dependent LTD at hippocampal excitatory synapses is generally considered to be endocannabinoid-independent in principal cells (Rouach and Nicoll, 2003; Nosyreva and Huber, 2005; Lanté et al., 2006). Similarly, excitatory synapses onto hippocampal and other cortical interneurons can readily undergo LTD (McMahon and Kauer, 1997; Laezza et al., 1999; Lu et al., 2007; Gibson et al., 2008; Nissen et al., 2010; Le Duigou et al., 2011; Edwards et al., 2012), but DGL- $\alpha$ has not yet been reported in GABAergic interneurons, and pharmacological experiments suggest that LTD in cortical interneurons may not require endocannabinoid signaling ( $\mathrm{Lu}$ et al., 2007; Gibson et al., 2008; Le Duigou et al., 2011; Edwards et al., 2012).

In contrast, by using a highly sensitive in situ hybridization approach, here we show that DGL- $\alpha$ is expressed by hippocampal interneurons, although at lower levels than in principal cells. By using an in vitro approach involving a pairing protocol to produce precisely timed sequential postsynaptic and presynaptic activity, we also provide pharmacological and genetic evidence that hippocampal principal cells and interneurons do exhibit endocannabinoidmediated LTD, which requires mGlu 5 , DGL- $\alpha$, and $\mathrm{CB}_{1}$ activity. Finally, the induction threshold of endocannabinoid-mediated LTD is cell type dependent, emphasizing that distinct circuit elements exploit this form of LTD under different physiological conditions.

\section{Materials and Methods}

Animals. Animal experiments were approved by the Committee of the Scientific Ethics of Animal Research (22.1/4027/003/2009) and were performed according to institutional guidelines of ethical code and the Hungarian Act of Animal Care and Experimentation (1998. XXVIII. Section 243/1998). Adult male C57BL/6H mice aged between P60 and P80 were used in the anatomical experiments, whereas the electrophysiological experiments were performed on hippocampal tissue derived from either wild-type $\mathrm{C} 57 \mathrm{BL} / 6$ mice (both genders), or their $\mathrm{CB}_{1}$ receptor knock-out littermates aged between P20 and P40 (Zimmer et al., 1999). To facilitate targeting of fast-spiking interneurons (FS INs), a transgenic mouse line on a FVB background expressing enhanced green fluorescent protein (EGFP) under the control of the parvalbumin promoter in bacterial artificial chromosome was also used (Meyer et al., 2002).

Tissue preparation for anatomical experiments. Adult male C57BL/6H mice ( $n=3$ for single in situ hybridization; $n=4$ for combined in situ hybridization and immunohistochemistry; $n=6$ for combined immunogold-immunoperoxidase staining) were perfused transcardially under deep pentobarbital anesthesia first with $0.9 \%$ saline and then with $4 \%$ paraformaldehyde (PFA) dissolved in $0.1 \mathrm{M}$ phosphate buffer (PB), $\mathrm{pH}$ 7.4. After perfusion, the brain was removed from the skull and cut into blocks, and 50- $\mu \mathrm{m}$-thick coronal sections containing the hippocampus were cut with a Leica Vibratome (Leica Microsystems).

In situ hybridization. Riboprobe preparation and in situ hybridization were performed as described previously (Katona et al., 2006), but including some important modifications to improve sensitivity. Briefly, a 1169bp-long segment of the mouse DGL- $\alpha$ coding sequence (GenBank accession number gi:33390900) was amplified by RT-PCR from cDNA derived from C57BL/6H mouse frontal cortex total mRNA. This segment of sequence in front of the stop codon was chosen, because it is absent in DGL- $\beta$, a closely related isoform of DGL- $\alpha$ (Bisogno et al., 2003). The sequences of primers were as follows: forward, $5^{\prime}$-TCA TGG AGG GGC TCA ATA AG; reverse, 5'-CTA GCG TGC CGA GAT GAC CA. PCR products were cloned into the SmaI site of pBluescript II SK ${ }^{-}$(Fermentas). The plasmid was linearized by EcoRV and BamHI digestion for the antisense and sense probes, respectively. After DNA cleaning procedure, a digoxigenin-labeled riboprobe was prepared by in vitro transcription as described previously (Katona et al., 2006). We and others reported previously that principal cells express very high levels of DGL- $\alpha$; however, hippocampal GABAergic interneurons were not visualized using conventional radioactive or nonradioactive procedures (Katona et al., 2006; Yoshida et al., 2006). To determine whether nonpyramidal cells express DGL- $\alpha$ at lower levels, we improved our approach at several points. To enhance preservation of DGL- $\alpha$ mRNA in GABAergic interneurons and to protect from exogenous RNases, a postfixation step was included in which hippocampal tissue blocks were intensely rinsed for $4 \mathrm{~h}$ in diethylpyrocarbonate (DEPC)-treated PB buffer containing 4\% PFA. After slicing in the presence of an RNase inhibitor (40 U; Roche Molecular Diagnostics) and DEPC-treated PB buffer, further incubation of hippocampal slices was performed in a free-floating manner. To increase the probability of probe binding, the hybridization temperature was decreased from 65 to $60^{\circ} \mathrm{C}$, and hybridization was performed for a longer period $(24 \mathrm{~h})$ in $1 \mathrm{ml}$ of hybridization buffer containing the digoxigeninlabeled riboprobe $(8.5 \mu \mathrm{g} / \mathrm{ml})$. The stringent hybridization buffer consisted of $50 \%$ formamide, $5 \times$ SSC, $1 \%$ SDS, $50 \mu \mathrm{g} / \mathrm{ml}$ yeast tRNA, and 50 $\mu \mathrm{g} / \mathrm{ml}$ heparin in DEPC-treated $\mathrm{H}_{2} \mathrm{O}$. During the incubation and the following three washing steps, the sections were vigorously rinsed on a shaker within a humid chamber. After incubation, the sections were first washed for $30 \mathrm{~min}$ at $60^{\circ} \mathrm{C}$ in high-stringency Wash Solution 1 (containing $50 \%$ formamide, $5 \times$ SSC, $1 \%$ SDS in DEPC-treated $\mathrm{H}_{2} \mathrm{O}$ ), and then twice for $45 \mathrm{~min}$ at $60^{\circ} \mathrm{C}$ in Wash Solution 2 (containing $50 \%$ formamide, $2 \times$ SSC in DEPC-treated $\mathrm{H}_{2} \mathrm{O}$ ). The sections were next washed for $5 \mathrm{~min}$ in $0.05 \mathrm{M}$ Tris-buffered saline containing $0.1 \%$ Tween 20 (TBST), pH 7.6, and then in a blocking solution in TBST containing 10\% normal goat serum (TBSTN) for $1 \mathrm{~h}$, both at room temperature. The sections were subsequently incubated overnight at $4^{\circ} \mathrm{C}$ with the primary antibody (sheep anti-digoxigenin Fab fragment conjugated to alkaline phosphatase) diluted at 1:1000. This antibody and all components of the reaction were obtained from Roche. The next day, sections were washed three times for $20 \mathrm{~min}$ in TBST, and then developed with freshly prepared chromogen solution in a total volume of $10 \mathrm{ml}$, containing $3.5 \mu \mathrm{l}$ of 5-bromo-4-chloro-3-indolyl-phosphate and $3.5 \mu \mathrm{l}$ of nitroblue tetrazolium chloride dissolved in chromogen buffer [containing the following (in mM): $100 \mathrm{NaCl} ; 100$ Tris-Cl, $\mathrm{pH} 9.5 ; 50 \mathrm{MgCl}_{2} ; 2$ (-)-tetramisole hydrochloride; and $0.1 \%$ Tween 20 ]. The sections were gently rinsed in 1 $\mathrm{ml}$ of the above developing solution in the dark at room temperature. Note that while DGL- $\alpha$ labeling appeared in principal cells within a few hours (Katona et al., 2006), visualization of hippocampal interneurons required longer incubation time (at least $12 \mathrm{~h}$ ). Finally, the sections were washed thoroughly in $0.1 \mathrm{M} \mathrm{PB}$, and in the case of the single in situ hybridization reaction, mounted in Vectashield (Vector Laboratories) onto glass slides, and coverslips were sealed with nail polish. Despite the enhanced reaction sensitivity, the in situ hybridization reaction developed only with the antisense riboprobe, and not with the identically processed control sense riboprobe (see Fig. $1 A, B$ ).

In situ hybridization combined with immunohistochemistry. After development of the in situ hybridization reaction, sections for combined in situ hybridization and immunohistochemistry were washed extensively in $0.1 \mathrm{M}$ PB. Subsequently, all washing steps and antibody dilutions were performed in Tris-buffered saline (TBS), pH 7.4 (0.05 M). After extensive washing in TBS (five times for $10 \mathrm{~min}$ each), sections were blocked in 5\% normal goat serum followed by incubation with the primary antibody of interest for $48 \mathrm{~h}$. As primary antibodies, either a monoclonal mouse anti-parvalbumin antibody (Swant; 1:2000), to visualize a major, aspiny population of GABAergic interneurons, or a monoclonal rat antisomatostatin antibody (Millipore; 1:200), to visualize the somatostatin/ $\mathrm{mGlu}_{1 \mathrm{a}}$-expressing population of hippocampal interneurons with 
filopodial spines, was used. Immunostaining with these antibodies resulted in the well characterized pattern of parvalbumin or somatostatin immunoreactivity of interneuron populations (Freund and Buzsáki, 1996), whereas no immunostaining was observed when the primary antibody was omitted from the reaction. After primary antibody incubation, sections were washed, and then incubated either with biotinylated anti-mouse IgG or with biotinylated anti-rat IgG (both in 1:500; Vector) according to the respective primary antibody treatment. The sections were then incubated in avidin biotinylated-horseradish peroxidase complex (Elite-ABC; $1: 500$ ) for $1.5 \mathrm{~h}$. This step was followed again by washing in TBS (twice for $20 \mathrm{~min}$ each). In the last step, the development of immunoperoxidase reaction was performed with the Vector NovaRED Peroxidase Substrate Kit according to the manufacturer's guideline, and the development time was 4 min. Finally, the sections were mounted in the nonaqueous mounting medium VectaMount (Vector). Lightmicroscopic analysis of immunostaining was performed with a Nikon Eclipse 80i upright microscope (Nikon Instruments).

Immunogold staining combined with immunoperoxidase histochemistry. Sections for electron microscopy first underwent an immunoperoxidase, and then an immunogold staining step. After perfusion, extensive washing, and a freeze-thawing protocol over liquid nitrogen to enhance antibody penetration, the sections were blocked in 5\% normal goat serum followed by incubation in a combination of two primary antibodies together for $48 \mathrm{~h}$. The following primary antibodies were used: an affinitypurified rabbit anti-DGL- $\alpha$ antibody designated "INT" (Katona et al., 2006) $(1: 3000 ; \sim 1 \mu \mathrm{g} / \mathrm{ml})$, which was coincubated with either a mouse monoclonal anti-parvalbumin IgG (Swant; 1:5000) or with a mouse monoclonal anti-mGlu ${ }_{1 a}$ IgG (a gift from Dr. Tamás Görcs, Semmelweis University, Budapest, Hungary; 1:30) (Kiss et al., 1996). The specificity of the anti-DGL- $\alpha$ antibody was confirmed in hippocampal sections derived from DGL- $\alpha$ knock-out mice (Ludányi et al., 2011). The monoclonal antibodies for interneuron markers have been characterized by the laboratory of origin and visualized the well known aspiny parvalbumin interneurons or the somatostatin/ $\mathrm{mGlu}_{1 \mathrm{a}}$-positive interneuron population with filopodial spines, as we described previously (Ouimet et al., 2004). After the primary antibody incubation, the sections were washed, and then incubated in the secondary antibody (biotinylated anti-mouse IgG; $1: 500$ for $2 \mathrm{~h}$ ). Next, the sections were incubated with avidin biotinylated-horseradish peroxidase complex (Elite-ABC; 1:500; $1.5 \mathrm{~h}$ ), followed again by washing in TBS (twice for 20 min each) and in Tris buffer (TB), pH 7.6 (twice for $20 \mathrm{~min}$ each). Finally, the immunoperoxidase reaction was developed using 3,3-diaminobenzidine (DAB) $(0.3 \mathrm{mg} / \mathrm{ml}$; SigmaAldrich) as chromogen and $0.01 \% \mathrm{H}_{2} \mathrm{O}_{2}$ dissolved in TB. After development of the immunoperoxidase reaction for markers of the hippocampal interneuron populations, which visualized their dendritic trees in great detail, the procedure was continued using high-resolution immunogold staining, which allows the localization of the target protein (DGL- $\alpha$ in this case) at a nanometer scale with the electron microscope. Hippocampal sections were extensively washed again and blocked with $0.8 \%$ bovine serum albumin and $0.1 \%$ cold-water fish skin gelatin for $3 \mathrm{~min}$. Sections were then incubated with a $0.8 \mathrm{~nm}$ gold-conjugated goat anti-rabbit secondary antibody (1:50; AURION) overnight at $4^{\circ} \mathrm{C}$. This step was followed again by washing in TBS (twice for $15 \mathrm{~min}$ each), fixing in $1 \%$ glutaraldehyde in TBS for $10 \mathrm{~min}$, washing again in TBS (twice for $10 \mathrm{~min}$ each), and in $0.1 \mathrm{M} \mathrm{PB}$ (three times for $10 \mathrm{~min}$ each). Finally, silver intensification was performed using the silver enhancement system R-GENT SE-EM according to the kit protocol (AURION). After development of the immunostaining, the sections were treated with $0.5 \% \mathrm{OsO}_{4}$, dehydrated in an ascending series of ethanol and acetonitrile solutions, and embedded in Durcupan ACM Fluka (Sigma-Aldrich). During dehydration, sections were also treated with $1 \%$ uranyl acetate in $70 \%$ ethanol for $20 \mathrm{~min}$. After overnight incubation in Durcupan, the sections were mounted onto glass slides, and coverslips were sealed by polymerization of Durcupan at $56^{\circ} \mathrm{C}$ for $48 \mathrm{~h}$. From sections embedded in Durcupan, areas of interest were reembedded and resectioned for electron microscopy. Sections were collected on Formvar-coated single-slot grids, stained with lead citrate, and examined with a Hitachi 7100 electron microscope (Hitachi High-Technologies Corporation).

To establish the subsynaptic or extrasynaptic distribution of DGL- $\alpha$ within dendritic shafts or filopodial spines of hippocampal interneurons, we performed a high-resolution quantitative evaluation of double staining at the electron-microscopic level. Only superficial ultrathin sections were collected (upper $5 \mu \mathrm{m}$ ) to avoid differences in penetration probabilities in the preembedding reaction. To determine background levels due to potential cross-reaction, sections treated in the same manner, but without the addition of the DGL- $\alpha$ primary antibody, were also investigated, and only 1 of 347 examined interneuron profiles $(n=2$ mice) contained a single gold particle. To be able to compare the distribution of DGL- $\alpha$ along the plasma membrane surface of interneuron dendrites or filopodial spines with the previous distribution data of DGL- $\alpha$ in hippocampal principal cells, we followed an analysis procedure previously described (Katona et al., 2006). Briefly, the length of plasma membrane from the edges of a synaptic junction was measured for every DGL- $\alpha$ positive spines or dendritic shaft and was divided into 60-nm-long bins. The localization of the gold particles representing DGL- $\alpha$ was measured as the distance between the closest edge of the postsynaptic density and the center of the immunoparticles present on the plasma membrane. Immunoreactive profiles for parvalbumin or $\mathrm{mGlu}_{1 \mathrm{a}}$ were first searched in the stratum radiatum or in the stratum oriens of the CAl region, respectively. Then the precise position of immunogold particles representing the DGL- $\alpha$ protein was analyzed in these dendritic profiles $(n=$ 25-25 gold particles of 214 and 182 profiles; $n=2$ mice). Electron micrographs were taken at 50,000 $\times$ magnifications, and the distance measurement was performed using the AnalySIS software (Olympus). For adjustment of the digital light and electron micrographs, Adobe Photoshop CS2 (Adobe Systems) was used. In all imaging processes, adjustments (brightness and contrast) were done in the whole frame and no part of an image was modified separately in any way.

Slice preparation for electrophysiological recordings. Mice were deeply anesthetized with isoflurane and subsequently decapitated. Brains were quickly removed from the skull and placed into ice-cold cutting solution containing the following (in mM): 205 sucrose, $2.5 \mathrm{KCl}, 1.25 \mathrm{NaH}_{2} \mathrm{PO}_{4}, 5$ $\mathrm{MgCl}_{2}, 0.5 \mathrm{CaCl}_{2}, 26 \mathrm{NaHCO}_{3}$, and 10 glucose. The cutting solution was saturated with $95 \% \mathrm{O}_{2}$ and $5 \% \mathrm{CO}_{2}$ (carbogen gas; $\mathrm{pH} 7.4 ; 290-300$ $\mathrm{mOsm} / \mathrm{L}$ ). After embedding brains into agarose (low gelling temperature agarose; $2 \%$ ), 200- $\mu \mathrm{m}$-thick coronal hippocampal slices were prepared using a VT1000S or a VT1200S microtome (Leica). To avoid hyperexcitability generated in recurrent networks of excitatory cells in the presence of $\mathrm{GABA}_{\mathrm{A}}$ receptor blockade, the CA3 region was removed from slices that were kept in an interface-type holding chamber at room temperature for at least $90 \mathrm{~min}$ before the recording. The holding chamber contained artificial CSF (ACSF) with the following composition (in mM): $126 \mathrm{NaCl}$, $2.5 \mathrm{KCl}, 1.25 \mathrm{NaH}_{2} \mathrm{PO}_{4}, 2 \mathrm{MgCl}_{2}, 2 \mathrm{CaCl}_{2}, 26 \mathrm{NaHCO}_{3}$, and 10 glucose, and were saturated with a mixture of $95 \% \mathrm{O}_{2}$ and $5 \% \mathrm{CO}_{2}, \mathrm{pH} 7.4$ $(280-290 \mathrm{mOsm} / \mathrm{L})$.

Electrophysiological recordings. Slices were transferred to a submersion type of recording chamber. To block $\mathrm{GABA}_{\mathrm{A}}$ receptor-mediated IPSCs, picrotoxin $(70-100 \mu \mathrm{M})$ was included in the ACSF. The flow rate was between 1.5 and $2 \mathrm{ml} / \mathrm{min}$. Recordings were performed at $31-32^{\circ} \mathrm{C}$ under visual guidance using an Olympus BX61 microscope or a Nikon FN1 microscope, equipped with differential interference contrast optics. EGFP in neurons was excited by a UV lamp, and the fluorescence was visualized using a CCD camera (C-7500; Hamamatsu). Whole-cell patch-clamp recordings were made using a Multiclamp 700B amplifier (Molecular Devices), filtered at $2 \mathrm{kHz}$ using the built-in Bessel filter of the amplifier. Data were digitized at $5 \mathrm{kHz}$ with a PCI-6024E or a PCI-6040E board (National Instruments), recorded with in-house data acquisition and stimulus software (Stimulog; courtesy of Prof. Zoltan Nusser, Institute of Experimental Medicine, Hungarian Academy of Sciences, Budapest, Hungary). Patch pipettes were pulled from borosilicate glass tubing with resistances of 3-5 M $\Omega$. To record EPSCs, the pipette solution contained the following (in $\mathrm{mm}$ ): $110 \mathrm{~K}$-gluconate, $4 \mathrm{NaCl}, 2 \mathrm{ATP}, 40$ HEPES, 0.3 GTP, and 2 biocytin, pH 7.4, 280-300 mOsm/L. In experiments including postsynaptic calcium buffer, $20 \mathrm{~mm} \mathrm{~K}$-gluconate were replaced by $20 \mathrm{~mm}$ BAPTA and either no additional $\mathrm{Ca}^{2+}$ or $2 \mathrm{~mm} \mathrm{Ca}^{2+}$ was added. Neurons recorded in hippocampal CA1 region were held at a holding potential of $-70 \mathrm{mV}$. Series resistance (between 5 and $21 \mathrm{M} \Omega$ ) was monitored throughout each experiment, and neurons with a change in series resistance of $>25 \%$ were excluded from the analysis. For extra- 
Table 1. Physiological properties of the recorded interneurons

\begin{tabular}{|c|c|c|c|c|}
\hline & Fast-spiking basket cells $(n=10)$ & Axo-axonic cells $(n=10)$ & Bistratified cells $(n=10)$ & 0 -LM cells $(n=10)$ \\
\hline Input resistance $(\mathrm{M} \Omega)$ & $70.82(60.94-88.64)^{a}$ & $111.41(70.96-137.1)$ & $117.26(91.01-146.6)$ & $136.8(86.59-199)$ \\
\hline Membrane time constant (ms) & $9.17(7.06-11.83)$ & $10.58(9.39-11.41)$ & $9.68(8.71-14.32)$ & $18.14(12.58-25.58)$ \\
\hline Membrane capacitance (pF) & $119(84-141)$ & $89(81-125)$ & $97(79-103)$ & $144(124-159)$ \\
\hline AP amplitude (mV) & $61.3(53.9-63.3)$ & $65.3(60.6-70.5)$ & $64.4(59.8-77)$ & $72.8(57.8-78)$ \\
\hline AP width at half-maximum (ms) & $0.4(0.4-0.5)$ & $0.5(0.4-0.5)$ & $0.4(0.3-0.5)$ & $0.6(0.5-0.8)$ \\
\hline AHP amplitude (mV) & $15.5(12.8-18)$ & $14.8(8.6-16.7)^{c}$ & $17.9(16-20.5)$ & $18.9(16.6-22)$ \\
\hline Spike frequency $(\mathrm{Hz})$ at large current steps ${ }^{e}$ & $61(50-84)$ & $77(56-114)$ & $66(41-101)$ & $65(51-78)$ \\
\hline Accommodation index at large current steps ${ }^{e}$ & $1.76(1.54-1.93)$ & $1.8(1.16-3.28)$ & $1.94(1.5-2.41)$ & $1.9(1.55-2.82)$ \\
\hline
\end{tabular}

Data are presented as the median and the interquartile range in parentheses. Values indicated with bold differ significantly $(p<0.05)$ from all other cell types, while values in italics indicate significant differences from two other cell types. $A P$, Action potential; AHP, afterhyperpolarization.

${ }^{a} \mathrm{FS} B C$ versus $\mathrm{AAC}, p=0.143 ; \mathrm{FS} B$ C versus BIST, $p=0.015 ; \mathrm{FS}$ BC versus $0-\mathrm{LM}, p=0.002$.

${ }^{b} \mathrm{BIST}$ versus $\mathrm{AAC}, p=0.222 ; \mathrm{BIST}$ versus $\mathrm{BC}, p=0.022 ; \mathrm{BIST}$ versus $0-\mathrm{LM}, p<0.001$.

'AAC versus FS BC, $p=0.356 ; A A C$ versus BIST, $p=0.043 ; A A C$ versus $0-\mathrm{LM}, p=0.015$.

${ }^{d}$ Voltage responses at which interneurons were capable to discharge continuously during the entire trace upon the smallest current injection ( $150-400 \mathrm{pA}$ range for FS IN and $50-250 \mathrm{pA} \mathrm{for} 0$-LM cells) were compared.

${ }^{e}$ Voltage responses at which interneurons fired with the highest frequency were compared.

cellular stimulation delivered at $0.1 \mathrm{~Hz}$, a theta electrode was filled with $\mathrm{ACSF}$ and placed into the stratum radiatum in the CA1 region of the hippocampal slice within $100-200 \mu \mathrm{m}$ of the recorded pyramidal cells and fast-spiking interneurons. For stimulation of oriens-lacunosum moleculare (O-LM) cells, the theta electrode was positioned in the stratum oriens. Before recording synaptic currents, we tested the voltage response to a series of hyperpolarizing and depolarizing square current pulses of $800 \mathrm{~ms}$ duration and amplitudes between -100 and $100 \mathrm{pA}$ at $10 \mathrm{pA}$ step intervals and then up to $250 \mathrm{pA}$ at $50 \mathrm{pA}$ step intervals from a holding potential of $-65 \mathrm{mV}$ in each cell. The voltage responses of neurons upon the current injections helped to distinguish interneurons of a fast-spiking character having no or small "sag" response to a hyperpolarizing current pulse from cells with lower spiking rate and a large sag, typical for O-LM cells (Maccaferri and McBain, 1996) (Table 1). Using these voltage responses, we characterized several physiological properties of distinct interneuron types. The input resistance, membrane capacitance, membrane time constant, and the relative sag amplitude was determined from the voltage responses to the hyperpolarizing current injections (Zemankovics et al., 2010). The action potential features and the firing characteristics were calculated from the voltage responses to the depolarizing current steps (Antal et al., 2006). Accommodation index was calculated as the ratio of the values for the last and the first interspike intervals. Since data were not normally distributed according to a Shapiro-Wilk test, nonparametric statistical tests were applied. Multiple groups of data were compared using the Kruskal-Wallis ANOVA test completed with comparison of samples as pairs with the Mann-Whitney $U$ test (Table 1).

LTD experiments. Two forms of LTD were studied at excitatory synapses onto CA1 pyramidal cells, fast-spiking basket, axo-axonic, bistratified, and O-LM interneurons. Spike timing-dependent LTD was induced by a post-pre pairing protocol. Before the pairing, the strength of presynaptic stimulation (varying between $20 \mu \mathrm{A}$ and $8 \mathrm{~mA}$ ) was adjusted to evoke EPSCs with amplitudes that were consistently larger than $50 \mathrm{pA}$. During the pairing protocol, an action potential in the postsynaptic neuron was evoked in current-clamp mode followed by stimulation of the excitatory inputs with a $10 \mathrm{~ms}$ delay. Together, 600 pulses were given in six blocks of 100 pairings at a membrane potential between -50 and -58 $\mathrm{mV}$. Pulse frequency was either 5 or $10 \mathrm{~Hz}$, and interblock interval was $10 \mathrm{~s}$. In the second protocol, LTD was induced pharmacologically by activation of group I metabotropic glutamate receptors ( $\mathrm{mGlu}$ ) with the agonist (S)-3,5-dihydroxyphenylglycine (DHPG) $(10$ or $50 \mu \mathrm{M})$ for 10 min. In some of these chemical LTD experiments, a pair of EPSCs with an interstimulus interval of $100 \mathrm{~ms}$ was evoked.

Analysis of electrophysiological experiments. Data were analyzed off-line using EVAN software (courtesy of Prof. Istvan Mody, University of California, Los Angeles, Los Angeles, CA). All data for each experiment were normalized relative to baseline and reported as mean \pm SEM. To reveal the presence of LTD, EPSC amplitudes were measured. To evaluate whether the induction protocol readily induced LTD within a given experiment, we compared the peak amplitudes measured in a 10-min-long control, preinduction period with those peak amplitudes that were determined in the last $5 \mathrm{~min}$ of the recordings after $25 \mathrm{~min}$ of the LTD induction (in both the post-pre pairing protocol and DHPG incubation experiment) using Student's $t$ test. Experiments involving pretreatments with an enzyme inhibitor [ $N$-formylL-leucine (1S)-1-[[(2S,3S)-3-hexyl-4-oxo-2-oxetanyl] methyl]dodecyl ester (THL)] or the receptor antagonists [2-methyl-6-(phenylethynyl)pyridine (MPEP), (S)-(+)- $\alpha$-amino-4-carboxy-2-methylbenzeneacetic acid (LY 367385), $N$-(piperidin-1-yl)-5-(4-iodophenyl)-1-(2,4-dichlorophenyl)-4methyl-1 $H$-pyrazole-3-carboxamide (AM 251), DL-2-amino-5-phosphonopentanoic acid (DL-AP5)] were analyzed in the same manner. To determine the efficacy of different treatments, EPSC amplitudes during the last $5 \mathrm{~min}$ after $25 \mathrm{~min}$ of the post-pre pairing or DHPG treatment were compared between the control and the treated groups using independentsamples $t$ test. In the case of the evaluation of $\mathrm{CB}_{1}$ function in LTD, experiments were performed in slices prepared from $\mathrm{CB}_{1}$ receptor knock-out mice and their littermates and the EPSC amplitudes were compared within the given experiments and between the two groups as described above. An $\alpha$ level of $p<0.05$ was considered statistically significant.

Anatomical identification of biocytin-filled neurons. After the recordings, hippocampal slices were fixed overnight in $4 \%$ paraformaldehyde in 0.1 M PB, pH 7.4. Following fixation, slices were washed with $0.1 \mathrm{M} \mathrm{PB}$ several times and incubated in a cryoprotecting solution (30\% sucrose in $0.1 \mathrm{M} \mathrm{PB}$; pH 7.4) for $2 \mathrm{~h}$. Slices were then freeze-thawed three times above liquid nitrogen and treated with $1 \% \mathrm{H}_{2} \mathrm{O}_{2}$ in $\mathrm{PB}$ for 15 min to reduce endogenous peroxidase activity. For single biocytin staining, biocytin-filled cells were visualized using avidin-biotin complex with horseradish peroxidase activity (ABC; Vector Laboratories). Ammonium nickel sulfate hexahydrate $\left[\left(\mathrm{NH}_{4}\right)_{2}\left(\mathrm{NiSO}_{4}\right)_{2} \cdot 6 \mathrm{H}_{2} \mathrm{O}\right.$; Sigma-Aldrich] was added to intensify the color reaction of 3-3-diaminobenzidine tetrahydrochloride (DAB-Ni) $(0.05 \%$ solution in Tris buffer, pH 7.4; Sigma-Aldrich) containing $0.015 \% \mathrm{H}_{2} \mathrm{O}_{2}$. After dehydration and embedding in Durcupan (SigmaAldrich), neurons were identified based on their dendritic and axonal arborization, and some representative cells were reconstructed as completely as possible with the aid of a drawing tube using a $40 \times$ objective. The anatomical classification of CA1 pyramidal neurons, bistratified cells, and O-LM cells could unequivocally be achieved based on morphological criteria after reconstruction of their axon arbor from non-resectioned whole slices (Freund and Buzsáki, 1996). To distinguish basket cells and axo-axonic cells, slices were resliced to $60-\mu \mathrm{m}$-thick sections and processed for immunofluorescence double labeling. Ankyrin G immunostaining was applied together with biocytin visualization as described previously (Gulyás et al., 2010). Briefly, sections were treated with $0.2 \mathrm{mg} / \mathrm{ml}$ pepsin (Dako) in $0.2 \mathrm{M} \mathrm{HCl}$ at $37^{\circ} \mathrm{C}$ for $15 \mathrm{~min}$ and were washed in $0.1 \mathrm{M} \mathrm{PB}$. Nonspecific binding sites were blocked in 10\% normal goat serum (Vector) in TBS, pH 7.4, followed by incubation with a mouse anti-ankyrin G antibody (1:100; Santa Cruz Bio- 
technology) diluted in TBS containing 2\% NGS and 0.05\% Triton X-100 for $72 \mathrm{~h}$ at $4^{\circ} \mathrm{C}$. Following several washes in TBS, Alexa 594-conjugated goat anti-mouse (1:200; Invitrogen) was used to visualize the ankyrin $\mathrm{G}$ immunostaining, and Alexa 488-conjugated streptavidin (1:500; Invitrogen) was used to label biocytin. Sections were then mounted on slides in Vectashield (Vector Laboratories). The staining was analyzed and images were taken by using an AxioImager.Z1 microscope (Zeiss). Subsequently, representative basket and axo-axonic cells were further developed by immunoperoxidase reaction using DAB-Ni for anatomical reconstruction (see above).

Drugs. All chemicals and drugs were obtained from Sigma-Aldrich, except THL, AM 251, 2,3-dioxo-6-nitro-1,2,3,4-tetrahydrobenzo[f] quinoxaline-7sulfonamide disodium salt (NBQX), DL-AP5, (5S,10R)-(+)-5-methyl10,11-dihydro-5 $H$-dibenzo $[a, d]$ cyclohepten-5,10-imine maleate (MK-801), MPEP hydrochloride, LY 367385, and DHPG, which were purchased from Tocris Bioscience. THL at $20 \mathrm{~mm}$, AM 251 at $100 \mathrm{~mm}$, and MPEP at $10 \mathrm{~mm}$ were dissolved in DMSO. Final DMSO concentration was always $<0.001 \%$. The $100 \mathrm{~mm}$ stock solutions were made of DL-AP5 and LY 367385 in $1 \mathrm{M} \mathrm{NaOH}$. DHPG and NBQX were dissolved in $\mathrm{H}_{2} \mathrm{O}$ at 50 and $100 \mathrm{mM}$, respectively. All drug stock solutions were stored at $-20^{\circ} \mathrm{C}$ before bath application. The final concentrations of receptor antagonists or the enzyme inhibitor were $100 \mu \mathrm{M}$ (DL-AP5 and LY 367385), $10 \mu \mathrm{M}$ (THL and MPEP), or $2 \mu \mathrm{M}$ (AM 251). DHPG was used at 10 or $50 \mu \mathrm{M}$. All of these drugs were present in the bath solution throughout the entire recording period except for DHPG. Slices were further preincubated with THL (10 $\mu \mathrm{M})$ for at least $30 \mathrm{~min}$ before beginning of the recording. MK-801 (1 mM) or BAPTA $(20 \mathrm{~mm})$ were dissolved in the intracellular solution and applied through the recording pipette.

\section{Results}

\section{DGL- $\alpha$ mRNA is present in hippocampal interneurons}

DGL- $\alpha$, the key enzyme for 2-AG synthesis, is highly expressed in hippocampal principal cells (Bisogno et al., 2003; Katona et al., 2006; Yoshida et al., 2006), and plays an indispensable function in several forms of retrograde synaptic signaling and plasticity at afferent GABAergic synapses onto hippocampal principal cells (Tanimura et al., 2010). To test the possibility that hippocampal GABAergic interneurons also exploit this serine hydrolase for synaptic signaling, we first used a modified, highly sensitive in situ hybridization protocol (for details, see Materials and Methods). This approach uncovered that hippocampal interneurons in fact also express DGL- $\alpha$ (Fig. 1). Varying the hybridization time and temperature as well as the development time of the reaction, different hippocampal cell types appeared at different stages and with different labeling intensity. The highest expression level of DGL- $\alpha$ was discernible in the subiculum and in CA1 and CA3 pyramidal neurons (Fig. $1 A, C, D)$. Significantly lower staining intensity was observed in CA2 pyramidal cells and in granule cells of the dentate gyrus, which indicates that the higher signal intensity in other principal cell types is not simply a consequence of high density of cell bodies packed in the pyramidal layer (Fig. $1 A, E)$. Scattered neurons in the hilus representing most probably glutamatergic mossy cells (Uchigashima et al., 2011) appeared at the same higher stringency temperature $\left(65^{\circ} \mathrm{C}\right)$ and with similar intensity as CA2 principal cells (Fig. $1 E$ ). A few faint nonpyramidal cells in the stratum oriens of both the CA1 and CA 3 subfields were already also visible at this temperature. Increasing the sensitivity of the reaction resulted in the labeling of numerous DGL$\alpha$-positive cell bodies resembling GABAergic interneurons throughout the hippocampal formation (Fig. $1 A$ ). These cell bodies were predominantly found in the stratum radiatum of the CA3 subfield and in the stratum oriens of the CA3 and CA1 regions, but labeled cells were also found at the border of stratum radiatum and stratum lacunosum-moleculare (Fig. $1 C, D$ ). The hilus of the dentate gyrus was also filled with DGL- $\alpha$ mRNAcontaining somata (Fig. $1 E$ ). Despite the higher sensitivity of the reaction, DGL- $\alpha$ mRNA signal did not reach detection threshold in several cell bodies distributed throughout all layers and subfields of the hippocampal formation (Fig. 1C-E). These cells often had smaller nuclei, which suggest that they may belong to glial cells or other GABAergic interneuron types. Nevertheless, it is important to emphasize that the absence of in situ hybridization reaction for DGL- $\alpha$ in these cells does not rule out the possibility that these cells also express DGL- $\alpha$ mRNA, albeit at an even lower expression levels. Importantly, in situ hybridization control experiments performed in parallel, but with the corresponding sense riboprobe did not result in any staining (Fig. $1 B$ ).

Together, these experiments suggest that DGL- $\alpha$ distribution is much more ubiquitous than reported previously, and its expression level varies considerably in a cell type-dependent manner.

\section{DGL- $\alpha$ mRNA is expressed by parvalbumin-containing and somatostatin/mGlu $\mathrm{ma}_{1 \mathrm{a}}$-positive hippocampal interneurons}

To provide direct evidence that the scattered DGL- $\alpha$ mRNAcontaining cell bodies belong to GABAergic interneurons and to gain further insight into which interneuron types express DGL- $\alpha$, we combined nonradioactive free-floating in situ hybridization and immunohistochemistry techniques. DGL- $\alpha$ is known to be strikingly compartmentalized in dendritic spine heads of pyramidal neurons at a perisynaptic position around the postsynaptic density of excitatory synapses (Katona et al., 2006; Yoshida et al., 2006). Therefore, we selected two well characterized interneuron populations for further study. The first population does not bear spines, but these cells receive the highest density of excitatory synapses onto dendritic shafts among aspiny interneuron types (Gulyás et al., 1999). The second population also receives a high density of excitatory synapses, but this innervation arrives onto elongated spine protrusions densely covering the dendritic tree (Baude et al., 1993). The former population can be visualized with strong immunostaining for parvalbumin, a neurochemical marker of inhibitory interneurons with a fast-spiking phenotype, whereas the latter population contains high levels of somatostatin, and sometimes weakly expresses parvalbumin (Maccaferri et al., 2000; Klausberger and Somogyi, 2008). Immunostaining for these neurochemical markers resulted in numerous scattered cell bodies throughout the hippocampus. Parvalbumin immunostaining was predominantly found in the principal cell layers, but sometimes also in strata oriens and radiatum (Fig. 2A,B), whereas somatostatin immunoreactivity was observed in the hilus of the dentate gyrus, in strata lucidum and oriens of the CA3 subfield, and in stratum oriens of the CA1 region (Fig. 2C,D). Notably, almost all of these interneurons expressed discernible levels of DGL- $\alpha$ mRNA and this high degree of colocalization was found in all regions of the hippocampal formation (Fig. 2). In the CA1 subfield, 116 of 117 parvalbumin-positive or somatostatinpositive cell bodies contained the purple precipitate representing the presence of DGL- $\alpha$ mRNA (58 and 59 cell bodies, respectively; $n=2$ animals). Control experiments running the two reactions, but omitting either the antisense riboprobe or the primary antibody did not result in costaining. Moreover, the possibility of a general cross-reaction could also be excluded based on the observation that DGL- $\alpha$-positive cells immunonegative for interneuron markers and even double-negative cell bodies were frequently found throughout the hippocampal formation (Fig. $2 A, C, D)$.

Collectively, these experiments provided direct evidence that at least two major immunohistochemically defined populations of hippocampal interneurons express the synthesizing enzyme for 2-AG. 

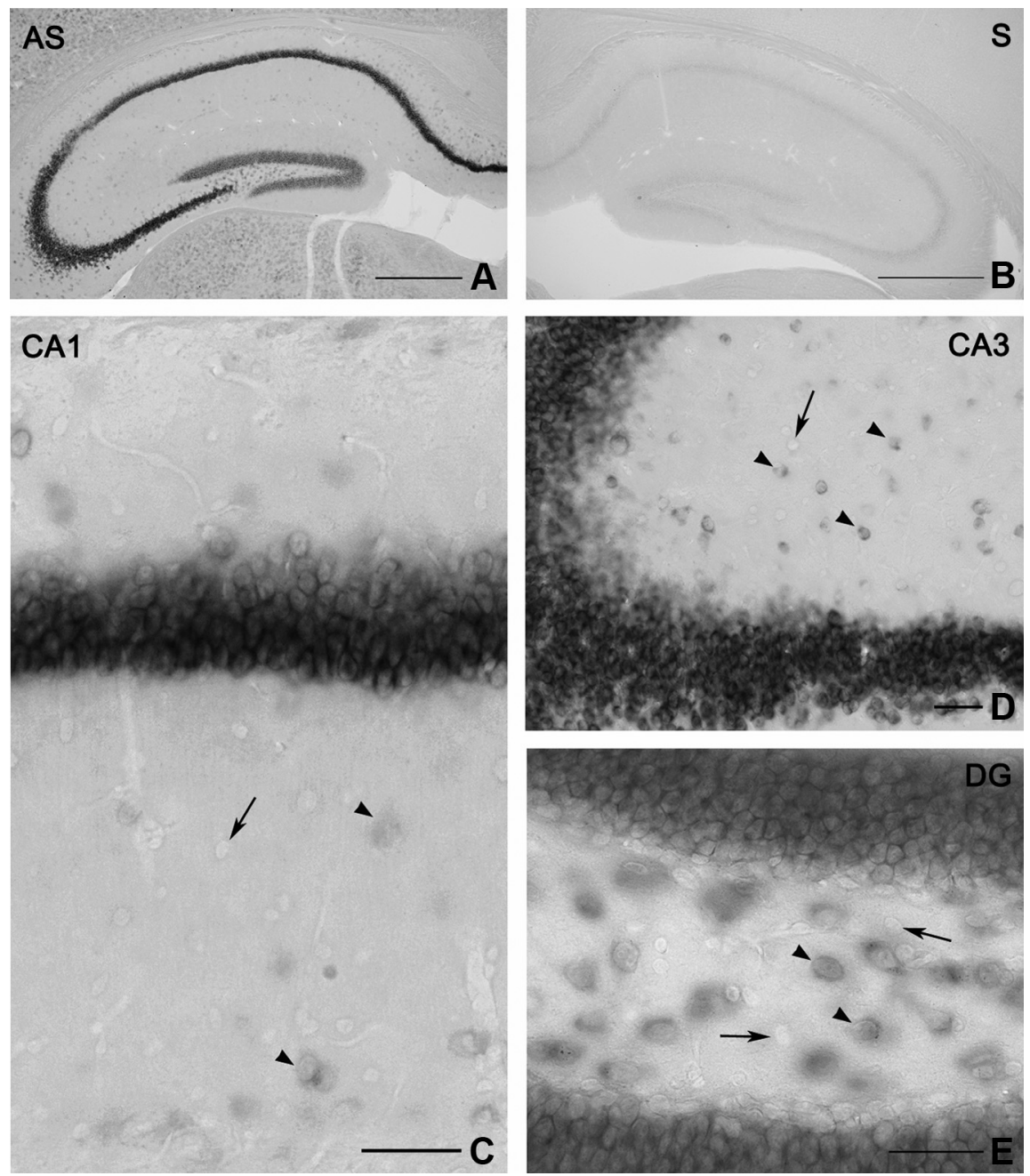

Figure 1. Different expression level of DGL- $\alpha$ mRNA in hippocampal principal cells and interneurons. $A$, Low-magnification light micrograph illustrates in situ hybridization using an antisense (AS) riboprobe for DGL- $\alpha$ in the hippocampus. The antisense probe predominantly visualizes the principal cell layers of the mouse hippocampus demonstrating that these cells express DGL- $\alpha$ at high levels. Granule cells in the dentate gyrus and pyramidal neurons in the CA2 subfield exhibit somewhat lower expression levels than pyramidal neurons in the CA1 and CA3 regions. In addition to principal neurons, cell bodies very weakly labeled for DGL- $\alpha$ are also distributed outside of the principal cell layers throughout the neuropil. $\boldsymbol{B}$, In contrast, in situ hybridization using a sense (S) riboprobe derived from the corresponding DGL- $\alpha$ sequence results in no labeling. $C$, At higher magnification, weakly labeled somata of putative GABAergic cells (arrowheads) are visible throughout the stratum oriens, the stratum radiatum, and at the border of stratum radiatum and stratum lacunosum-moleculare of the CA1 subfield. Note that some cell bodies (arrow) still remained DGL- $\alpha$-negative under these reaction conditions, indicating an even weaker expression level of DGL- $\alpha$ or a complete absence of expression of this lipase in these cells. $\boldsymbol{D}$, Numerous DGL- $\alpha$-positive interneurons are also distributed throughout the stratum radiatum of the CA3 region (depicted by arrowheads), but DGL- $\alpha$-negative cells were also observed (arrow). $\boldsymbol{E}$, In the hilus, $\mathrm{DGL}-\alpha$-positive cell bodies either belong to the glutamatergic neurons called mossy cells or to GABAergic interneurons. The arrowheads label DGL- $\alpha$-positive cells, whereas DGL- $\alpha$-negative cells are indicated by arrows. Scale bars: $A, B, 500 \mu \mathrm{m}$; C $-E, 50 \mu \mathrm{m}$.

\section{Perisynaptic DGL- $\alpha$ is concentrated at afferent glutamatergic synapses of hippocampal interneurons}

To determine whether the DGL- $\alpha$ enzyme protein is also present in hippocampal interneurons as well as to reveal the precise subcellular localization of DGL- $\alpha$ in these cells, we performed immunogold staining for DGL- $\alpha$ combined with immunoperoxidase staining for interneuron markers. The specificity of the antibody for DGL- $\alpha$ in the mouse hippocampus has been validated in DGL- $\alpha$ knock-out mice (Ludányi et al., 2011). Because somatostatin immunostaining labels only the somata, but not the dendrites of interneuron populations with filopodial spines, we exploited the fact that $\mathrm{mGlu}_{1 \mathrm{a}}$ densely covers the plasma membrane of these cells (Baude et al., 1993). Immunostaining for $\mathrm{mGlu}_{1 \mathrm{a}}$ outlines their complete dendritic tree, including the spines, at great detail both at the light and electron microscopic levels. The electron-dense $\mathrm{DAB}$ end product of the immunoperoxidase reaction revealed numerous aspiny parvalbumin-positive dendrites in the stratum radiatum of the CA1 region (Fig. $3 A, B$ ). Combined immunoperoxidase and immunogold stainings demonstrated that DGL- $\alpha$ is indeed found on the plasma membrane of parvalbumin-positive hippocampal interneurons (Fig. $3 A, B$ ). The immunogold particles representing the position of the enzyme protein were always attached to the intracellular side of the plasma membrane in accordance with the intracellular position of the respective epitope used to generate the DGL- $\alpha$ antibody (Fig. $3 A, B)$. These dendrites were heavily innervated by putative glutamatergic synapses forming asymmetric connections with characteristic postsynaptic densities (Fig. $\left.3 A_{1}, A_{2}\right)$. Notably, distribution analysis of the gold particles in relation to these excitatory synapses revealed that the vast majority of DGL- $\alpha$ is excluded from the synaptic cleft, and is found in a characteristic perisynaptic position similarly to the position observed in hippocampal pyramidal neurons (Figs. $3 A_{1}-B_{2}, 4 A$ ). In addition, $\mathrm{mGlu}_{\mathrm{la}}$ immunopositive dendrites were frequently found in the stratum oriens of the CA1 region, but these dendrites carried numerous elongated filopodial spines (Fig. 3C,D). When the DAB precipitate did not mask the postsynaptic density, it was possible to visualize three to five asymmetric synapses onto these spines (Fig. 3C). These $\mathrm{mGlu}_{1 \mathrm{a}}$ positive spine heads also contained DGL- $\alpha$, which accumulated in a perisynaptic position (Figs. 3C,D, $4 B$ ) as described previously in the case of Glu $_{1 \mathrm{a}}$ (Baude et al., 1993). To further quantify the precise localization of DGL- $\alpha$, the synaptic and extrasynaptic plasma membrane was dissected into 60$\mathrm{nm}$-long bins and every gold particle depicting DGL- $\alpha$ was assigned to a given bin based on its distance from the edge of the postsynaptic density. In both interneuron types, the majority $(>60 \%)$ of the immunogold labeling was found within the first two bins, which indicates the presence of a 120 -nm-thick perisynaptic ring formed by DGL- $\alpha$ proteins around the edge of excitatory synapses (Fig. 4) (see Materials and Methods for further analysis details).

Together, the electron microscopic analysis demonstrates that the synthesizing enzyme of the endocannabinoid 2-AG is concentrated perisynaptically around the postsynaptic density of excitatory synapses onto the dendritic shafts of aspiny parvalbumin-positive interneurons and the dendritic spines of somatostatin/mGlu $\mathrm{ma}_{1 \mathrm{a}}$-positive interneurons, in addition to 
its widespread distribution at afferent excitatory synapses of pyramidal cells.

\section{The induction threshold for spike timing-dependent LTD of excitatory synapses varies among different populations of hippocampal neurons} The ubiquitous postsynaptic presence of DGL- $\alpha$ at excitatory synapses makes its product $2-\mathrm{AG}$ a potential candidate to mediate LTD in both principal cells and GABAergic interneurons. However, earlier studies proposed that neither neuron population exhibits an endocannabinoid-mediated form of LTD (Rouach and Nicoll, 2003; Nosyreva and Huber, 2005; Lanté et al., 2006; Le Duigou et al., 2011). To resolve this controversy, we used a post-pre pairing protocol, which requires subsequent postsynaptic and presynaptic activity in a precisely timed manner to induce LTD. During these experiments, focal electrical stimulation of glutamatergic afferent fibers evoked excitatory currents (EPSCs) in recorded postsynaptic neurons. After an at least 10-min-long baseline period, we switched to current-clamp mode and evoked action potentials in the postsynaptic neuron, which were followed by extracellularly evoked EPSPs. To monitor potential changes in the EPSC amplitude after pairing of the neuronal firing with the presynaptic excitatory input, we then switched back to voltage-clamp mode and continued recording for another 20-30 min. EPSC amplitudes recorded during the last $5 \mathrm{~min}$ of this recording period were compared with amplitudes during the prestimulation period (for details, see Fig. $6 \mathrm{~A}$ and Materials and Methods).

Whole-cell patch-clamp recordings were performed in different types of neurons in the CA1 region of hippocampal slices. Only those neurons that could be unequivocally identified as either CA1 pyramidal cells $(n=126)$, fast-spiking basket cells $(n=67)$ (Fig. 5A), axo-axonic cells $(n=26)$ (Fig. $5 B)$, bistratified cells $(n=32)$ (Fig. $5 C)$, or O-LM cells $(n=95)$ (Fig. $5 D)$ based on their dendritic and axonal arborization as well as on their physiological properties (Table 1) were included in the electrophysiological analysis. In the category of FS INs, we pooled the data obtained in LTD experiments from fast-spiking basket cells, axoaxonic cells, and bistratified cells, because these data were statistically similar.

Postsynaptic action potentials paired with EPSPs arriving with a time delay of $10 \mathrm{~ms}$ at $5 \mathrm{~Hz}$ readily induced spike timing-dependent LTD (tLTD) in CA1 pyramidal cells, but not in either FS INs nor in O-LM cells (Fig. 6A, Table 2). Lower DGL- $\alpha$ level in hippocampal interneurons (Fig. $1 C$ ) raised the possibility that these cells require stronger stimulation than pyramidal neurons to produce sufficient 2-AG to elicit LTD. To investigate whether interneurons may have a higher threshold for LTD induction, pairing of the postsynaptic action potential discharge with EPSPs was also performed at $10 \mathrm{~Hz}$. Remarkably, robust
tLTD of similar magnitude ( $>30-40 \%)$ could be detected in all three major types of hippocampal neurons ( $p=0.128$; Fig. $6 B$, Table 2). The pairing protocol delivered at 5 or $10 \mathrm{~Hz}$ in pyramidal cells produced comparable tLTD in magnitude $(p=0.325$; Fig. 6C, Table 2).

Collectively, these findings demonstrate that tLTD can be induced at excitatory synapses on both pyramidal cells and interneurons, but the threshold for tLTD induction is higher in interneurons compared with pyramidal cells in the CA1 hippocampal region.

\section{Characteristics of tLTD at hippocampal excitatory synapses}

Postsynaptic spiking alone (i.e., without pairing with EPSPs) delivered at $10 \mathrm{~Hz}$ did not alter the amplitude of synaptic currents (pyramidal cells, $0.977 \pm 0.014$ of control, $n=4, p=0.13$; FS INs, $1.01 \pm 0.04$ of control, $n=4, p=0.96$; O-LM cells, $0.984 \pm$ 0.021 of control, $n=3, p=0.43$ ), indicating the associative nature of this form of LTD in all cell types. Next, we tested the magnitude of LTD as a function of the time delay of EPSPs following the action potentials. Pairing of the action potentials with EPSPs with a time delay of $30 \mathrm{~ms}$ at $10 \mathrm{~Hz}$ induced a smaller change in the EPSC amplitude than the pairing with the time 

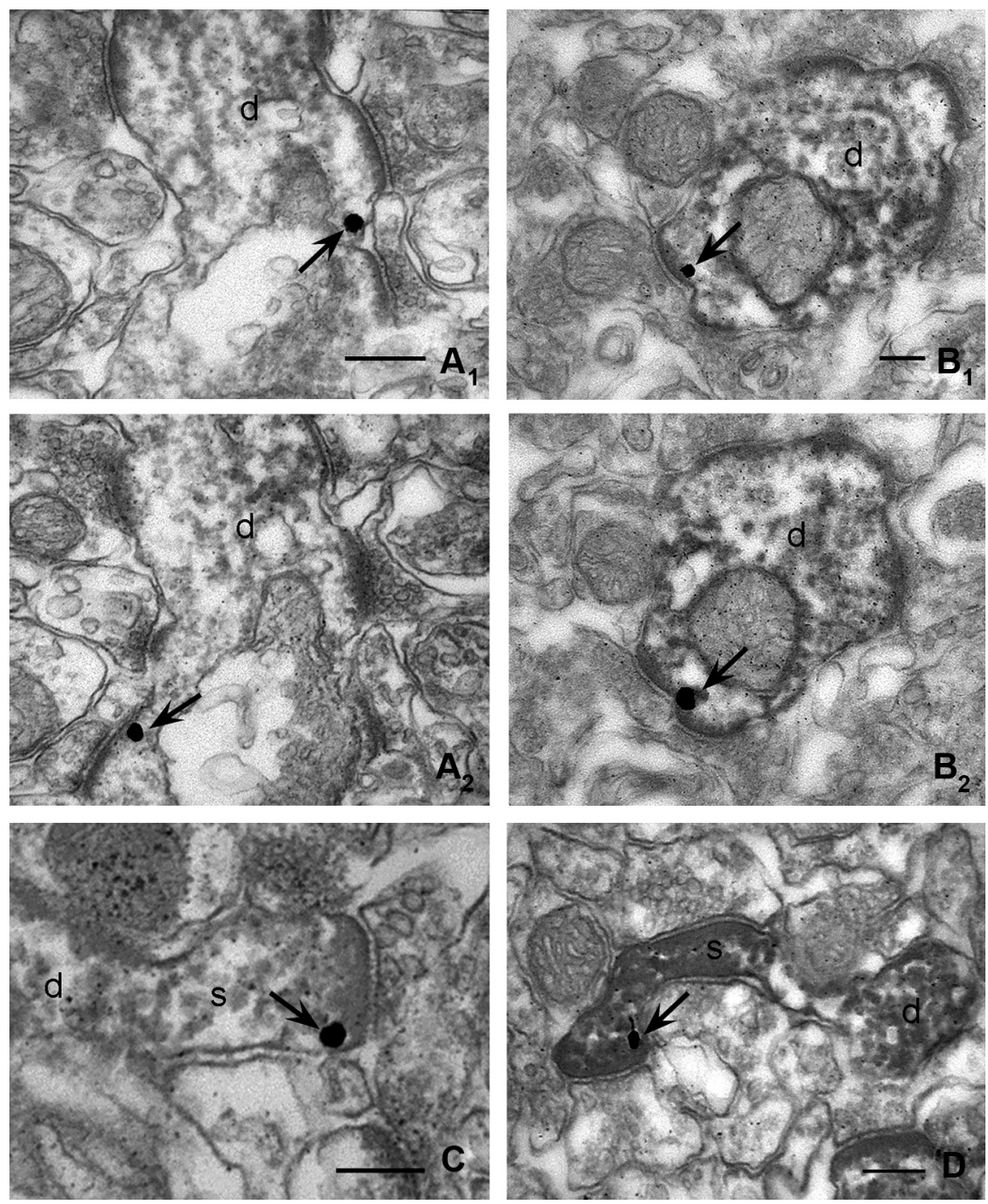

Figure 3. DGL- $\alpha$ is localized at excitatory synapses on interneuron dendrites and spines in the hippocampus. $\boldsymbol{A}, \boldsymbol{B}$, High-power electron micrographs demonstrate DGL- $\alpha$ and PV colocalization in the hippocampus. High-resolution preembedding immunogold staining for DGL- $\alpha$ (arrows point to immunogold particles representing the position of the lipase) reveals that this enzyme is attached to the intracellular surface of the plasma membrane of interneuronal dendritic shafts. Moreover, DGL- $\alpha$ is found in a striking perisynaptic position adjacent to the postsynaptic density of excitatory synapses (d) indicating that even aspiny interneuron dendrites compartmentalize the molecular machinery for endocannabinoid mobilization in a similar manner as spiny pyramidal cell dendrites. The black dense end product of the immunoperoxidase reaction (DAB) identifies PV-containing interneurons. Electron micrographs are taken from the stratum radiatum of $C A 1$ ( $\boldsymbol{A}_{1}$ and $\boldsymbol{A}_{2}$, and $\boldsymbol{B}_{1}$ and $\boldsymbol{B}_{2}$ are serial sections). $\boldsymbol{C}, \boldsymbol{D}$, High-power electron micrographs from the stratum oriens of CA1 show that DGL- $\alpha$ is localized at glutamatergic synapses of spiny inhibitory cells. The dendritic processes of these cells are labeled by $\mathrm{mGlu}_{1 \mathrm{a}}$ immunoreactivity (visualized by the electron-dense black DAB precipitate). High-resolution preembedding immunogold staining for $\mathrm{DGL}-\alpha$ provides evidence that this lipase is present on the plasma membrane of dendritic spines (s) protruding from the dendritic shafts (d) of this interneuron type around asymmetric, putative glutamatergic synapses. Immunogold particles are indicated by arrows. Note that excitatory axon terminals forming synapses on these interneuron populations are immunonegative for $\mathrm{DGL}-\alpha$ and for both neurochemical markers. Scale bars: $\boldsymbol{A}-\boldsymbol{D}$, $200 \mathrm{~nm}$.

delay of $10 \mathrm{~ms}$ (pyramidal cells, $0.814 \pm 0.098$ of control, $n=4$, $p=0.15$; FS INs, $0.679 \pm 0.052$ of control, $n=4, p=0.01$; O-LM cells, $0.797 \pm 0.033$ of control, $n=3, p=0.03$ ). In contrast, no change in EPSC amplitude was observed, when EPSPs were evoked $50 \mathrm{~ms}$ after the action potential (pyramidal cells, $0.997 \pm$ 0.037 of control, $n=5, p=0.98$; FS INs, $0.995 \pm 0.027$ of control, $n=4, p=0.78$; O-LM cells, $0.987 \pm 0.035$ of control, $n=4, p=$ $0.75)$, suggesting the importance of the precise timing of postsynaptic cell activity in relation to the arrival of presynaptic inputs. Previous studies established that somewhat similar forms of
tLTD (although induced with different stimulation frequencies and pairing protocols) at excitatory synapses of cortical principal cells require the activation of presynaptic ionotropic NMDA receptors (Sjöström et al., 2003; Rodríguez-Moreno and Paulsen, 2008; Min and Nevian, 2012). Therefore, we first repeated the 10 $\mathrm{Hz}$ pairing protocol using the $10 \mathrm{~ms}$ delay in the presence of $100 \mu \mathrm{M}$ DL-AP5, an NMDA receptor antagonist. Bath application of this antagonist caused no change in tLTD in pyramidal cells and FS INs, whereas this treatment prevented the induction of tLTD in O-LM cells (Table 2). In contrast, when the noncompetitive NMDA receptor blocker, MK-801 was included in the pipette solution, tLTD was readily induced in O-LM cells (0.569 \pm 0.051 of control; $n=4 ; p=0.004)$. Under our recording conditions, intrapipette application of MK-801 almost fully eliminated pharmacologicallyisolatedNMDAreceptormediated EPSCs within $10 \mathrm{~min}$ after breaking into the cells $(0.104 \pm 0.028$ of control; $n=6 ; p=0.002)$, confirming the ability of MK-801 to block NMDA receptor channel function upon intracellular application. These data indicate that this form of tLTD is dependent on NMDA receptor activation only in O-LM cells, but these ionotropic glutamate receptor channels necessary for tLTD are not present postsynaptically on O-LM cells.

\section{tLTD at excitatory synapses is mediated} by endocannabinoid signaling

In the next set of experiments, we sought to determine the molecular cascade mediating tLTD in CAl neurons using the post-pre pairing protocol with the time delay of $10 \mathrm{~ms}$ at $10 \mathrm{~Hz}$. First, we recorded neurons in the presence of $10 \mu \mathrm{M}$ MPEP, an antagonist of $\mathrm{mGlu}_{5}$, and found that tLTD could not be induced in CA1 pyramidal cells or in interneurons (Fig. $7 A$, Table 2). Next, we tested whether elevation of intracellular $\mathrm{Ca}^{2+}$ in the postsynaptic neuron is necessary for tLTD. Including the $\mathrm{Ca}^{2+}$ chelator BAPTA (20 $\mathrm{mM})$ either alone or in addition to $2 \mathrm{mM}$ $\mathrm{Ca}^{2+}$ (which allows potentially permissive PLC $\beta$ activity) into the pipette solution indeed fully eliminated tLTD in all tested neuron types in both cases (Fig. 7B, Table 2). In the hippocampus, group I mGlu stimulation leads to the biosynthesis of DAG, the precursor of $2-\mathrm{AG}$ in a $\mathrm{Ca}^{2+}$-dependent manner, which requires DGL- $\alpha$ activity (Jung et al., 2005, 2007). Hence, we aimed to clarify the potential role of DGL- $\alpha$ in tLTD. In the presence of the DAG lipase blocker, THL $(10 \mu \mathrm{M})$, tLTD could not be induced in pyramidal cells or in interneurons (Fig. $7 C$, Table 2). Given the recent genetic evidence indicating that DGL- $\beta$, a related isoform of DGL- $\alpha$, does not contribute to $2-A G$ synthesis in the adult 

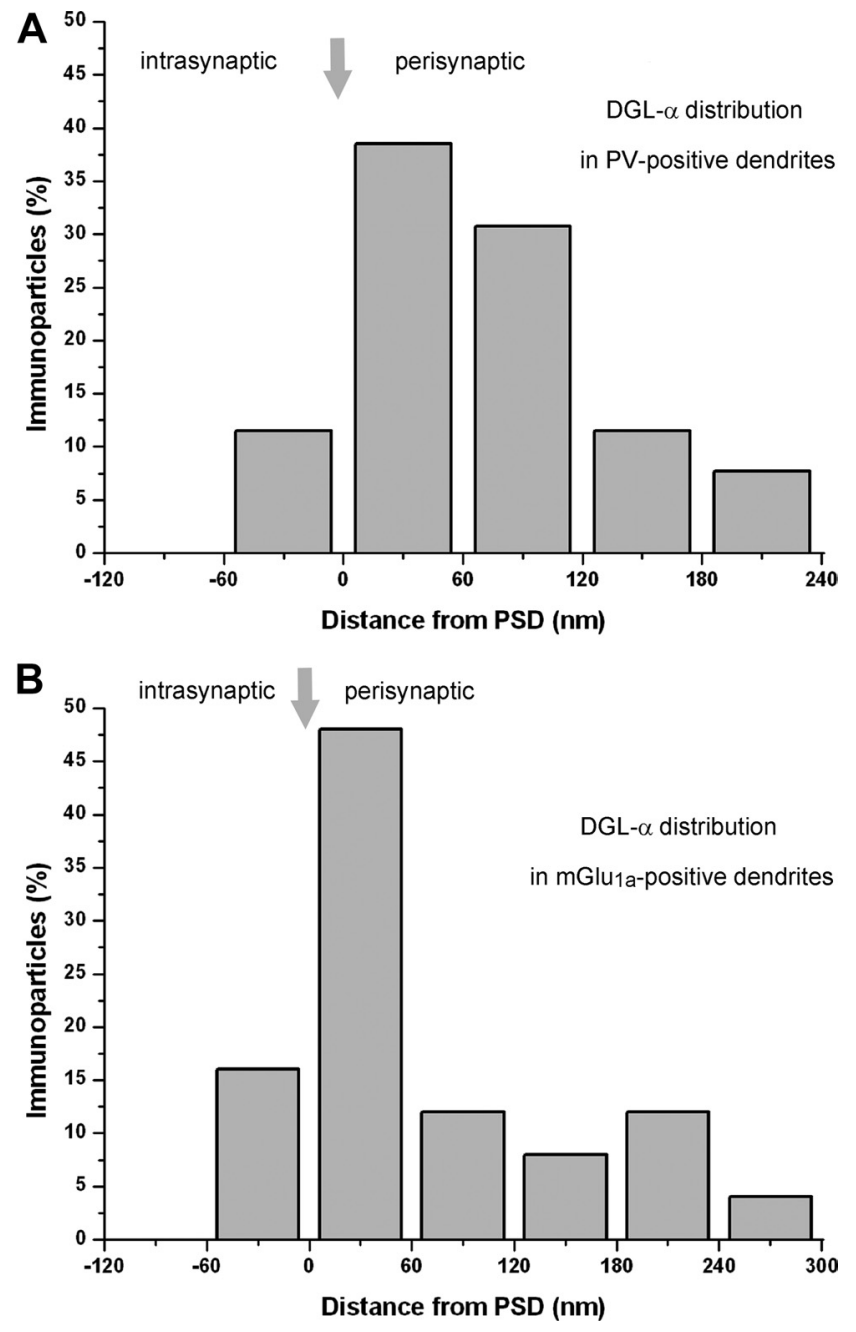

Figure 4. Distribution of DGL- $\alpha$ is compartmentalized in a perisynaptic zone at excitatory synapses on interneuron dendrites and spines in the hippocampus. $\boldsymbol{A}, \boldsymbol{B}$, Spatial distribution of immunogold particles representing DGL- $\alpha$ in relation to excitatory synapses on hippocampal CA1 interneuron subpopulations containing either parvalbumin $(\boldsymbol{A})$ or $\mathrm{mGlu}_{1 \mathrm{a}}(\boldsymbol{B})$. The distance of immunogold particles from the edge of the synaptic junction (indicated as " 0 " on the $x$-axis and by the arrows) were measured along the plasma membrane, which was divided into 60 $\mathrm{nm}$-wide compartments. Negative values indicate distance toward the intrasynaptic region; positive values indicate distance away from the postsynaptic density. Data are expressed as the percentage of immunogold particles at a given distance compartment compared with all gold particles found in the profile immunoreactive for the particular interneuron marker ( $n=25-$ $25 ; 2$ animals). Images used for the analysis were taken either from the stratum radiatum of the CA1 subfield $(\boldsymbol{A})$ or from the stratum oriens of $C A 1(\boldsymbol{B})$. The measurements gave similar results in the two interneuron populations and are in accordance with previous data demonstrating that DGL- $\alpha$ is rarely found intrasynaptically. Instead, this endocannabinoid-synthesizing enzyme is preferentially targeted to a perisynaptic annulus around the postsynaptic specialization of excitatory synapses for both CA1 pyramidal neurons and GABAergic interneurons.

hippocampus (Tanimura et al., 2010), our results therefore suggest that DGL- $\alpha$ is required for tLTD in all three major population of neurons in the hippocampus. Finally, we investigated the potential contribution of the receptor of $2-A G$, the $\mathrm{CB}_{1}$ cannabinoid receptor, to tLTD using hippocampal slices prepared from wild-type or $\mathrm{CB}_{1}$ knock-out mice. While robust tLTD was observed in CA1 neurons in wild-type mice, the same pairing protocol did not evoke changes in the EPSC amplitude in pyramidal cells or in interneurons recorded in slices derived from $\mathrm{CB}_{1}$ knock-out littermates (Fig. 7D, Table 2).

Together, these results provide direct evidence for the require- ment of retrograde endocannabinoid signaling in spike timingdependent LTD at excitatory synapses of pyramidal cells and interneurons.

\section{Chemical LTD at excitatory synapses also requires endocannabinoid signaling}

The involvement of $\mathrm{mGlu}_{5}$ in endocannabinoid-mediated tLTD in the hippocampus poses the question whether activation of group I mGlu receptors per se is sufficient to induce LTD at excitatory synapses onto both pyramidal cells and hippocampal interneurons. To address this issue, we pharmacologically activated group I mGlu receptors by bath application of DHPG. We found that $10 \mu \mathrm{M}$ DHPG induced significant LTD only in pyramidal cells, but not in FS INs or O-LM cells (Fig. 8A, $B$, Table 3 ). In contrast, DHPG at a higher concentration $(50 \mu \mathrm{M})$ readily induced LTD in pyramidal cells and in both populations of hippocampal interneurons (Fig. $8 A, B$, Table 3 ). Thus, these observations are in accordance with the finding obtained with our post-pre pairing protocol demonstrating that stronger stimulation is necessary for the induction of LTD in interneurons compared with pyramidal cells.

In the final set of experiments, we examined the pharmacological profile of chemical LTD in pyramidal cells and interneurons. We observed that application of DHPG $(50 \mu \mathrm{M})$ did not evoke LTD in any of the studied cell types in the presence of 10 $\mu \mathrm{M}$ MPEP (Fig. 8 B, Table 3). In contrast, LY 367385, a specific antagonist of $\mathrm{mGlu}_{1}$ receptors, significantly reduced but did not eliminate LTD in pyramidal cells and FS INs. Interestingly, this compound fully blocked LTD in O-LM cells expressing high levels of $\mathrm{mGlu}_{1 \mathrm{a}}$ (Table 3$)$. The inclusion of BAPTA $(20 \mathrm{~mm})$ into the pipette solution in the absence or presence of $2 \mathrm{mM} \mathrm{Ca}^{2+}$ prevented LTD after $50 \mu \mathrm{M}$ DHPG treatment in all three cell types (Fig. $8 A, B$, Table 3 ). Similarly to tLTD, group I mGlu-dependent LTD could not be detected in slices preincubated with $10 \mu \mathrm{M}$ THL (Fig. 8 B, Table 3), indicating the involvement of $2-A G$ in this chemical form of LTD. However, variable effects were observed in the presence of $2 \mu \mathrm{M}$ AM 251, a CB ${ }_{1}$ receptor antagonist. While this antagonist did not affect chemical LTD in pyramidal cells, it could prevent LTD in FS INs and O-LM cells (Table 3). In contrast, the same DHPG treatment did not result in LTD in slices prepared from $\mathrm{CB}_{1}$ knock-out mice but induced robust LTD in slices derived from wild-type littermates (Fig. 8A, B, Table 3).

To evaluate whether the changes in EPSC amplitudes in chemical LTD experiments are due to a presynaptic or postsynaptic mechanism, a pair of EPSCs with an interstimulus interval of $100 \mathrm{~ms}$ was evoked, which allowed us to monitor the alterations in paired-pulse ratios of synaptic currents. In pyramidal cells, we observed that the paired-pulse ratio is significantly increased in parallel with LTD induction upon DHPG treatment (control: $1.83 \pm 0.11$; in $10 \mu \mathrm{M}$ DHPG: $2.37 \pm 0.25, n=5, p=$ 0.035; control: $1.67 \pm 0.12$; in $50 \mu \mathrm{M}$ DHPG: $2.86 .1 \pm 0.46, n=$ $11, p=0.031)$, but no change was detected in $\mathrm{CB}_{1}$ knock-out mice (control: $1.59 \pm 0.24$; in $50 \mu \mathrm{M}$ DHPG: $2.057 \pm 0.37, n=8$, $p=0.24)$. Similarly, when LTD was induced by $50 \mu \mathrm{M}$ DHPG application in FS INs or O-LM cells, the paired-pulse ratio was significantly increased (FS INs, control: $2.96 \pm 0.48$; in $50 \mu \mathrm{M}$ DHPG: $6.9 \pm 1.92, n=11, p=0.049$; O-LM cells, control: $2.26 \pm$ 0.34 ; in $50 \mu \mathrm{M}$ DHPG: $3.63 \pm 0.51, n=5, p=0.024)$. In contrast, but as in pyramidal cells, if LTD was not induced in an interneuron, its paired-pulse ratio was unchanged (FS INs, control: $2.11 \pm 0.12$; in $10 \mu \mathrm{M}$ DHPG: $1.95 \pm 0.14, n=9, p=0.35$; control: $2.45 \pm 0.11$; in KO mice after $50 \mu \mathrm{M}$ DHPG: $3.18 \pm 0.81$, $n=8, p=0.33$; O-LM cells, control: $3.15 \pm 0.55$; in $10 \mu \mathrm{M}$ 
A
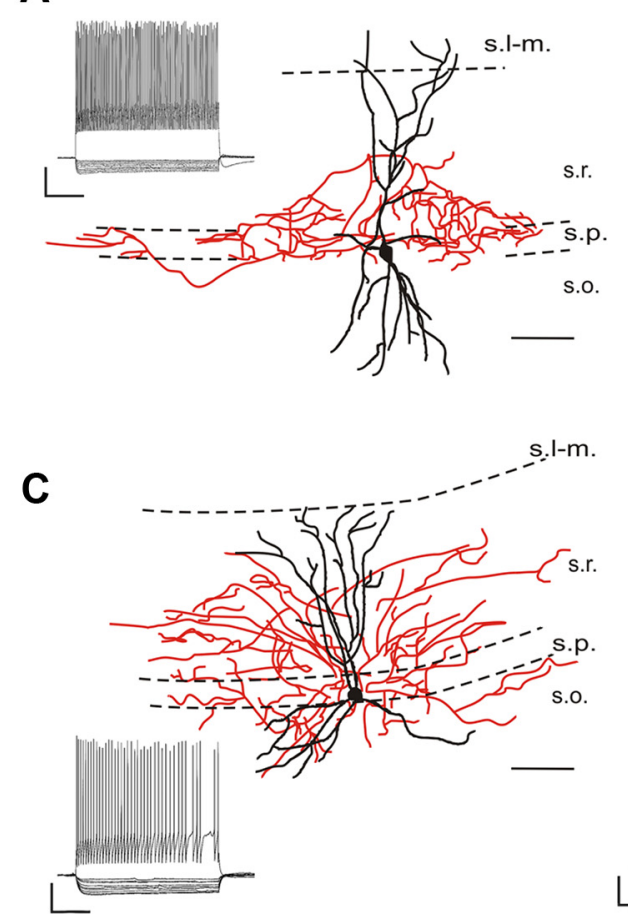

B
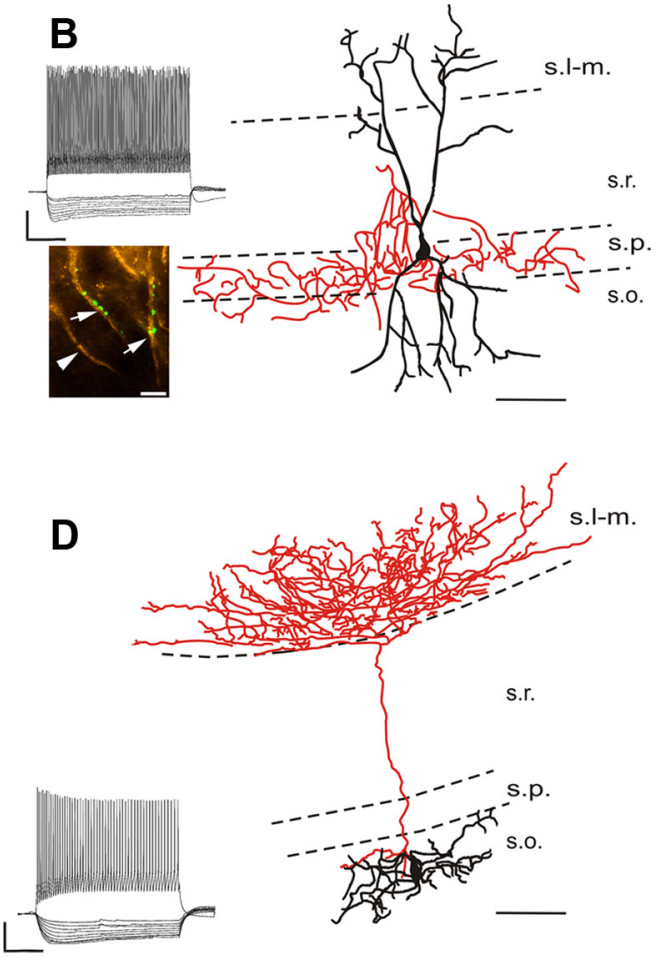

Figure 5. Light-microscopic reconstructions and voltage responses to current steps of the studied interneurons types in the CA1 region of the hippocampus. Representative members of the three morphologically distinct interneuron types showing a fast-spiking basket cell $(\boldsymbol{A})$, an axo-axonic cell ( $\boldsymbol{B})$, a bistratified cell ( $\boldsymbol{C}$, and an 0-LM cell (D). Dendrites are represented in black and axons are visualized in red. Scale bars: $100 \mu \mathrm{m}$. The arrows in the inset in $\boldsymbol{B}$ show two ankyrin G-immunostained axon initial segments (yellow) that are surrounded by biocytin-labeled boutons (green). This labeling unequivocally identifies axo-axonic cells at the light-microscopic level. The arrowhead indicates an axon initial segment receiving no labeled boutons from this interneuron. Scale bar: $5 \mu \mathrm{m}$. For each cell, voltage responses to depolarizing ( $400 \mathrm{pA}$ ) and hyperpolarizing current steps (from -10 to - 100 pA in increments of $10 \mathrm{pA}$ ) are shown. Calibration: $200 \mathrm{~ms}, 20 \mathrm{mV}$. s.l-m., Stratum lacunosum-moleculare; s.r., stratum radiatum; s.p., stratum pyramidale; s.o., stratum oriens.

DHPG: $3.77 \pm 0.56, n=5, p=0.06$; control: $2.29 \pm 0.72$; in $\mathrm{KO}$ mice after $50 \mu \mathrm{M}$ DHPG: $1.82 \pm 0.34, n=3, p=0.36)$.

These results highlight that group I mGlu receptor activation with DHPG is sufficient to induce strong LTD at excitatory synapses onto CA1 pyramidal cells and hippocampal interneurons. This form of synaptic plasticity has comparable molecular mechanisms to the tLTD triggered with a post-pre pairing protocol, and its expression is consistent with presynaptic changes in neurotransmitter release. Finally, these experiments demonstrate that retrograde 2-AG signaling is necessary for both forms of LTD in all three subpopulations of hippocampal neurons examined here.

\section{Discussion}

In the present study, we report two forms of LTD, both of which are mediated via retrograde endocannabinoid signaling at afferent excitatory synapses onto hippocampal glutamatergic pyramidal cells and specific GABAergic interneurons. Interestingly, both forms of LTD exhibit cell type-specific induction thresholds. Several lines of experimental findings support this conclusion: (1) DGL- $\alpha$, a synthesizing enzyme of the endocannabinoid 2-AG (Bisogno et al., 2003), is expressed not only by principal cells but also by two populations of GABAergic hippocampal interneurons characterized either by the neurochemical markers parvalbumin or by somatostatin/mGlu $\mathrm{m}_{1 \mathrm{a}}$ receptors. (2) DGL- $\alpha$ accumulates perisynaptically at excitatory synapses received by these interneuron populations. (3) The excitatory synaptic inputs of these interneurons and also of pyramidal cells in the CA1 region readily undergo spike timing-dependent LTD. This form of LTD is absent, when DGL- $\alpha$ or $\mathrm{CB}_{1}$ cannabinoid receptor function is blocked. (4) The same syn- apses exhibit robust LTD induced by DHPG, an agonist of group I mGlu receptors known to mobilize 2-AG (Jung et al., 2005), and this chemical form of LTD is mechanistically similar to tLTD. (5) Both forms of LTD have higher induction thresholds in these hippocampal interneurons than in pyramidal neurons.

\section{Endocannabinoid-LTD in hippocampal pyramidal neurons}

Recent advances led to the appreciation that induction and expression of LTD is mechanistically diverse and may require several independent molecular signaling cascades (Feldman, 2009; Collingridge et al., 2010). One of these cascades uses endocannabinoids to signal backward across synapses and permanently silence presynaptic activity (Gerdeman et al., 2002; Marsicano et al., 2002; Robbe et al., 2002), but several other forms of LTD do not require endocannabinoid signaling (Collingridge et al., 2010). This mechanistic and molecular heterogeneity is apparent using similar induction protocols in a synapse-specific manner (Crozier et al., 2007) or at different developmental stages (Yasuda et al., 2008). For example, tLTD in excitatory cells is dependent on $\mathrm{CB}_{1}$ function at certain neocortical excitatory synapses (Sjöström et al., 2003; Bender et al., 2006; Nevian and Sakmann, 2006; Crozier et al., 2007), but not in others (Crozier et al., 2007; Banerjee et al., 2009). However, despite the widespread expression of group I mGlus, DGL- $\alpha$ and $\mathrm{CB}_{1}$ receptors at hippocampal excitatory synapses (Lujan et al., 1996; Katona et al., 2006; Yoshida et al., 2006), and the reliable inducibility of tLTD at excitatory synapses onto principal cells (Debanne et al., 1994; Niehusmann et al., 2010), involvement of retrograde endocannabinoid signaling in a spike timing-dependent form of synaptic plasticity has not previously been demonstrated in hippocampal 

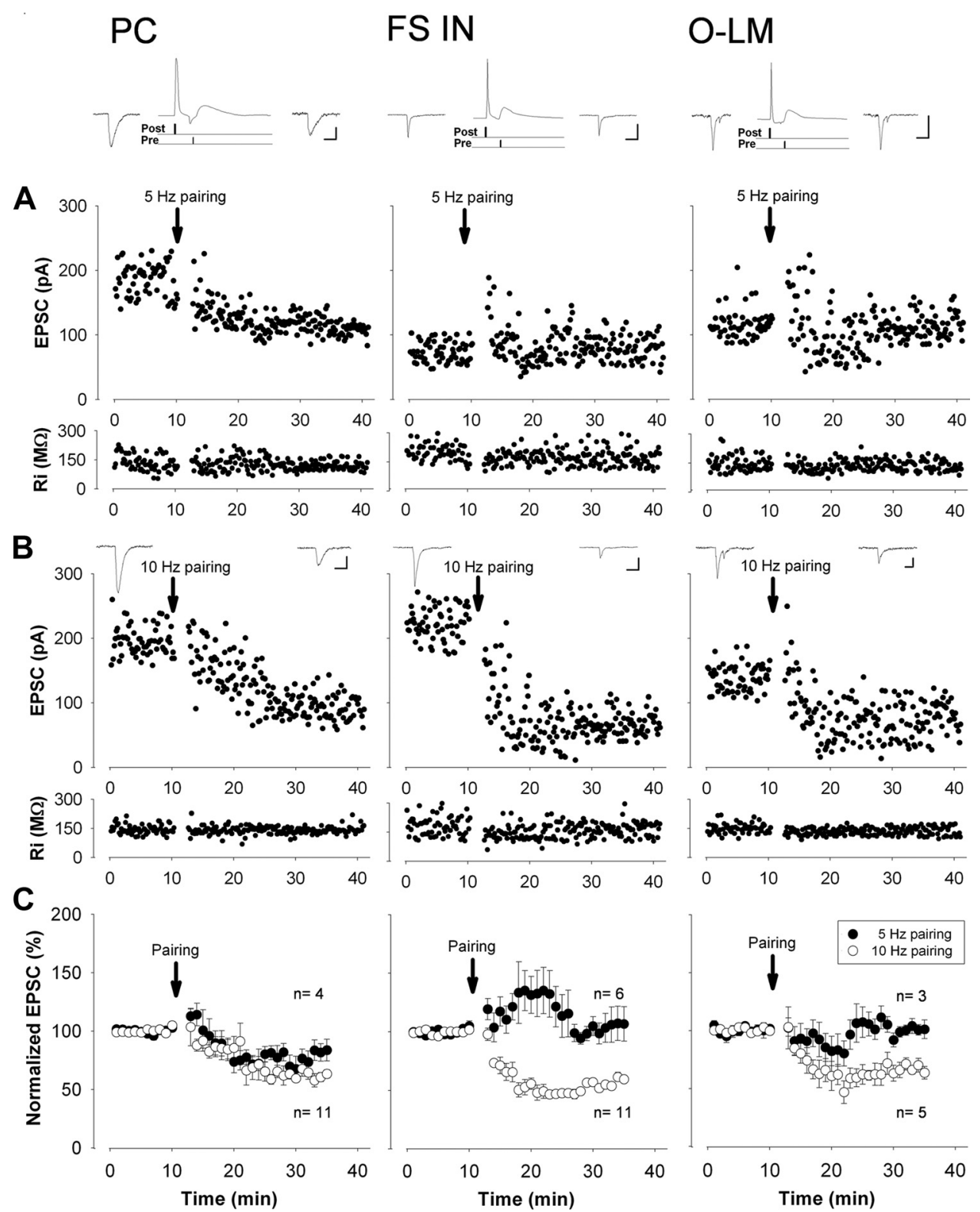

Figure 6. A stronger post-pre pairing protocol is necessary for the induction of tLTD at excitatory synapses onto interneurons than onto pyramidal cells in the CA1 subfield of the hippocampus. $A$, Representative experiments showing the presence or absence of long-lasting changes in EPSC amplitude after pairing of action potential discharge with stimulation of excitatory fibers at $5 \mathrm{~Hz}$. Time graphs of EPSC amplitude and input resistance recorded in different cell types. The insets above the graphs depict the averaged records of five consecutive EPSCs taken just before and 25 min after the pairing, respectively. In between, the schematic drawings of the post-pre pairing protocol together with the corresponding responses are also presented. $\boldsymbol{B}$, If the postsynaptic cell firing was paired with the presynaptic input at $10 \mathrm{~Hz}$, tLTD was induced in each cell type. C, Summary graphs of percentage change of EPSC amplitude after pairing the postsynaptic firing with the presynaptic stimulation at 5 or $10 \mathrm{~Hz}$ is illustrated in comparison with baseline values before pairing. In pyramidal cells, both protocols induced tLTD. In contrast, only the $10 \mathrm{~Hz}$, but not the $5 \mathrm{~Hz}$ pairing protocol induced tLTD in interneurons. For details, see Table 2. All data points on the plots represent a mean \pm SEM of six consecutive events. Differences in baseline values in the case of individual cells are likely due to their different inputs. PC, Pyramidal cells; FS IN, fast-spiking interneurons, including basket cells, axo-axonic cells, and bistratified cells; 0-LM, 0-LM cells. Calibration: $10 \mathrm{~ms}, 60 \mathrm{pA}$.

neurons. Moreover, despite the consistent manifestation of mGlu-LTD (Palmer et al., 1997; Huber et al., 2001), and the presence of a somewhat similar form of LTD at GABAergic synapses (Chevaleyre and Castillo, 2003), uncertainty remains whether this chemical form of LTD requires retrograde endocannabinoid signaling at excitatory synapses onto hippocampal principal cells. While pharmacological blockade of $\mathrm{CB}_{1}$ receptors did not prevent DHPG-induced LTD at excitatory synapses in both previous and the current study (Rouach and Nicoll, 2003; Nosyreva and Huber, 2005; Lanté et al., 2006; Izumi and Zorumski, 2012), we demonstrated by using genetic inactivation that
DHPG-LTD requires $\mathrm{CB}_{1}$ receptors, in agreement with a recent report using higher concentrations of DHPG (Xu et al., 2010). Our study further extends this conclusion by uncovering the indispensable role of DGL- $\alpha$ activity in DHPG-LTD, and reveals the participation of the endocannabinoid 2-AG in long-term depression of excitatory inputs received by hippocampal excitatory cells.

A potential explanation for these contradicting results may be the observation that $\mathrm{CB}_{1}$ antagonists are less capable to antagonize $\mathrm{CB}_{1}$-dependent depression of excitatory synaptic transmission than of inhibitory synaptic transmission in the hippocampus 
Table 2. Effects of the pairing protocol on EPSC amplitude in distinct cell types and the outcome of different drug treatments or genetic inactivation of $C_{1}{ }_{1}$ receptors on the magnitude of tLTD

\begin{tabular}{|c|c|c|c|c|c|c|c|c|c|}
\hline & \multicolumn{3}{|l|}{ Pyramidal cell } & \multicolumn{3}{|l|}{ FSIN } & \multicolumn{3}{|l|}{0 -LM cell } \\
\hline & $\%$ & $n$ & $p$ & $\%$ & $n$ & $p$ & $\%$ & $n$ & $p$ \\
\hline Pairing at $5 \mathrm{~Hz}$ & $0.735 \pm 0.028$ & 4 & 0.046 & $1.049 \pm 0.060$ & 6 & 0.55 & $0.910 \pm 0.030$ & 3 & 0.188 \\
\hline Pairing at $10 \mathrm{~Hz}$ & $0.582 \pm 0.023$ & 11 & $<0.001$ & $0.591 \pm 0.015$ & 11 & $<0.001$ & $0.674 \pm 0.018$ & 5 & $<0.001$ \\
\hline$+\mathrm{AP5}$ & $0.642 \pm 0.031$ & 4 & 0.982 & $0.426 \pm 0.082$ & 4 & 0.060 & $0.960 \pm 0.020$ & 4 & 0.002 \\
\hline+ MPEP & $0.999 \pm 0.033$ & 7 & $<0.001$ & $1.002 \pm 0.015$ & 10 & $<0.001$ & $0.850 \pm 0.026$ & 4 & 0.023 \\
\hline+ BAPTA, $0 \mathrm{~mm} \mathrm{Ca}^{2+}$ & $0.926 \pm 0.018$ & 4 & $<0.001$ & $0.975 \pm 0.028$ & 3 & $<0.001$ & $0.995 \pm 0.028$ & 3 & 0.002 \\
\hline+ BAPTA, $2 \mathrm{~mm} \mathrm{Ca}^{2+}$ & $1.029 \pm 0.031$ & 6 & $<0.001$ & $1.074 \pm 0.046$ & 6 & $<0.001$ & $0.977 \pm 0.064$ & 4 & 0.001 \\
\hline$+\mathrm{THL}$ & $0.991 \pm 0.010$ & 8 & $<0.001$ & $0.957 \pm 0.032$ & 7 & $<0.001$ & $0.947 \pm 0.028$ & 7 & 0.003 \\
\hline $\mathrm{CB}_{1} \mathrm{KO}$ & $0.990 \pm 0.022$ & 10 & $<0.001$ & $0.980 \pm 0.019$ & 8 & $<0.001$ & $1.114 \pm 0.030$ & 3 & 0.018 \\
\hline
\end{tabular}

Data are expressed as mean \pm SEM. Student's paired $t$ test was used to evaluate the significant changes in post-pre pairing experiments conducted at 5 or $10 \mathrm{~Hz}$ compared with baseline values (first two rows). In the drug treatment experiments, independent-samples $t$ test was used for the statistical comparison between data obtained with $10 \mathrm{~Hz}$ pairing in the absence or the presence of different drugs, or in the measurements conducted in slices prepared from wild-type or $\mathrm{CB}_{1}$ knock-out mice.

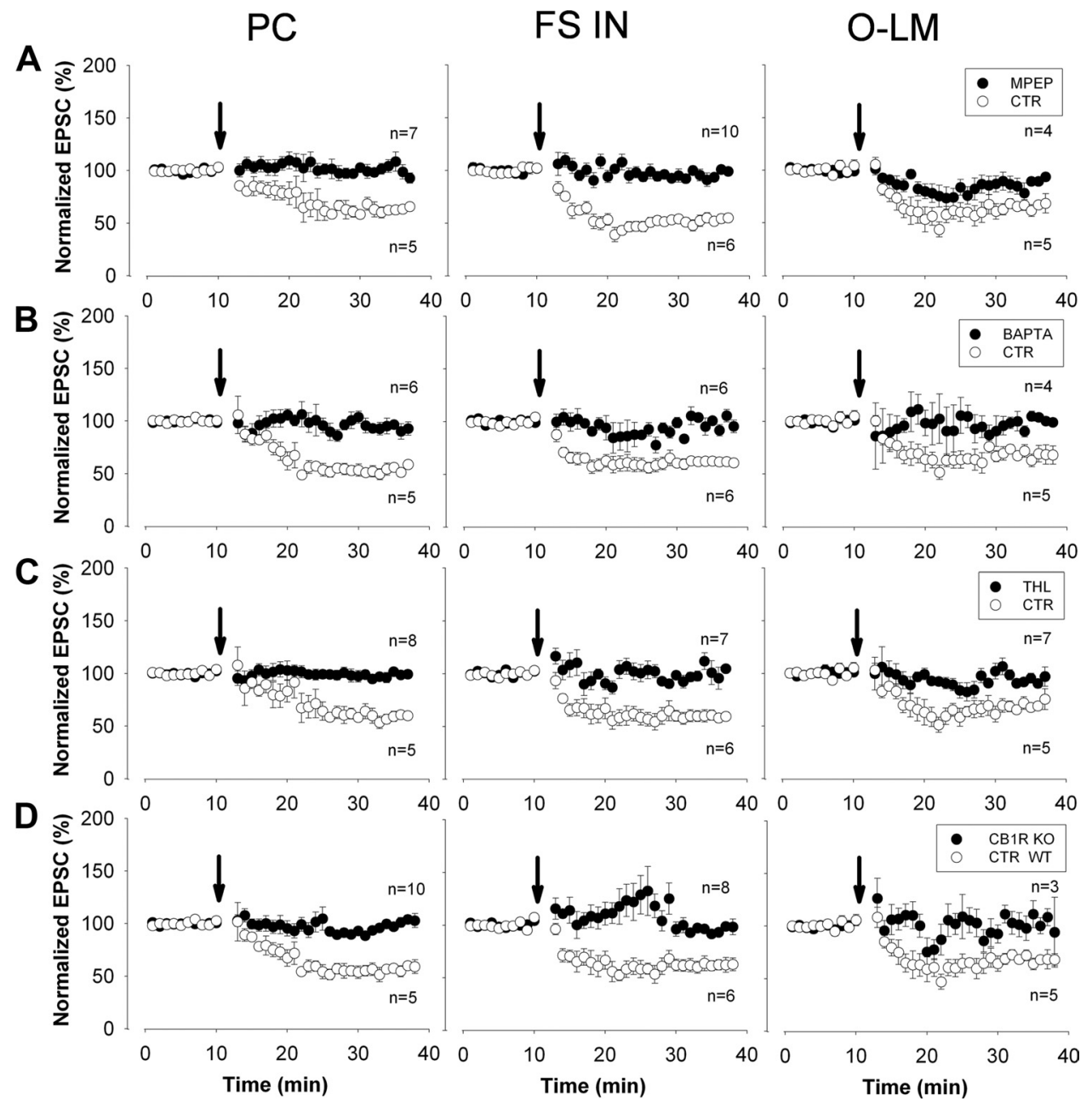

Figure 7. Pharmacological and genetic approaches identify the molecular elements involved in the induction of $10 \mathrm{~Hz}$ tLTD. $A$, The tLTD phenomenon is blocked in both pyramidal cells and interneurons during perfusion of the mGlu $u_{5}$ antagonist MPEP $(10 \mu \mathrm{m})$; using a pipette solution containing $20 \mathrm{~mm}$ BAPTA (B) or during the perfusion of the DAG lipase blocker THL (10 $\left.\mu \mathrm{M}\right)(\boldsymbol{C})$. D, The tLTD phenomenon is not present in slices prepared from $C_{1}$ receptor knock-out mice. The results are plotted and compared with data obtained from their wild-type littermates. In the presence of MPEP, normalized EPSCs in 0-LM cells significantly differed from control $(p=0.02)$, but not from baseline amplitudes $(p=0.08)$. For all other numerical details and respective statistical analysis, see Table 2. All data points on the plots represent mean \pm SEM of six consecutive events. PC, Pyramidal cells; FS IN, fast-spiking interneurons, including basket cells, axo-axonic cells, and bistratified cells; 0-LM, 0-LM cells.

(Hajos and Freund, 2002), implicating that synapse-specific differences may exist in the molecular organization or in the density of presynaptic $\mathrm{CB}_{1}$ receptors (Ohno-Shosaku et al., 2002). An experimental preparation-dependent variability in the contribution of astrocytic $\mathrm{CB}_{1}$ receptors to synaptic plasticity is also emerging and may underlie some of the discrepancies in the mag- nitude and direction of synaptic plasticity (Navarrete and Araque, 2010; Han et al., 2012; Min and Nevian, 2012). Finally, the ratio of $\mathrm{mGlu}_{1} / \mathrm{mGlu}_{5}$ contribution to DHPG-induced LTD may also differ between experimental paradigms (Izumi and Zorumski, 2012) and can be cell type specific as observed in the present study. Nevertheless, the $\mathrm{mGlu}_{5}$-specific antagonist MPEP 

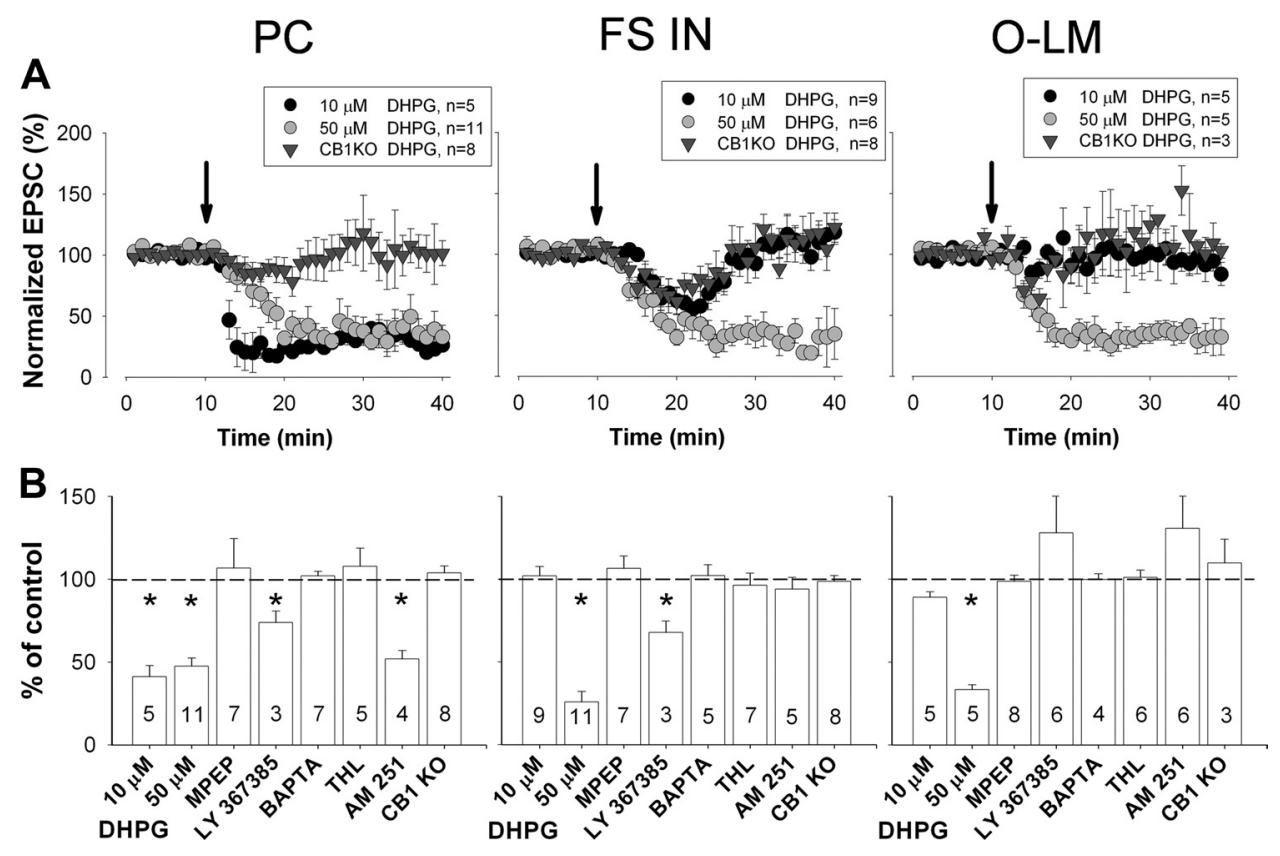

Figure 8. The group I mGlu agonist DHPG induces LTD of excitatory synapses onto CA1 hippocampal interneurons and pyramidal cells by triggering retrograde endocannabinoid signaling. $A$, Concentration dependence of chemical LTD induction in pyramidal cells and in interneurons by DHPG. The summary plots of the EPSC amplitudes show that a higher concentration of DHPG is necessary to induce LTD in interneurons compared with pyramidal cells. However, even this higher concentration of DHPG was unable to induce LTD in slices prepared from C $B_{1}$ knock-out mice. $\boldsymbol{B}$, Summary of the effects of pharmacological and genetic manipulations on the magnitude of $50 \mu \mathrm{m}$ DHPG-induced LTD. All data are expressed as percentage change relative to control values (mean \pm SEM). The arrows indicate the addition of DHPG at $10 \mathrm{~min}$. DHPG was applied for $10 \mathrm{~min}$ (between 10 and $20 \mathrm{~min}$ ). The number of cells in different conditions is shown inside the bars. ${ }^{*} p<$ 0.05 .

Table 3. Effects of DHPG on EPSC amplitudes in distinct cell types and the outcome of different drug treatments or genetic inactivation of $\mathrm{CB}_{1}$ receptors on the magnitude of chemical LTD

\begin{tabular}{|c|c|c|c|c|c|c|c|c|c|}
\hline & \multicolumn{3}{|l|}{ Pyramidal cell } & \multicolumn{3}{|l|}{ FSIN } & \multicolumn{3}{|l|}{ 0-LM cell } \\
\hline & & $n$ & $p$ & & $n$ & $p$ & & $n$ & $p$ \\
\hline $10 \mu \mathrm{M}$ DHPG & $0.346 \pm 0.071$ & 5 & $<0.001$ & $1.019 \pm 0.049$ & 9 & 0.165 & $0.891 \pm 0.026$ & 5 & 0.315 \\
\hline $50 \mu \mathrm{M}$ DHPG & $0.483 \pm 0.049$ & 11 & $<0.001$ & $0.258 \pm 0.064$ & 11 & $<0.001$ & $0.333 \pm 0.029$ & 5 & 0.002 \\
\hline +MPEP & $1.006 \pm 0.177$ & 7 & 0.011 & $1.064 \pm 0.075$ & 7 & $<0.001$ & $0.989 \pm 0.038$ & 8 & $<0.001$ \\
\hline$+\mathrm{LY} 367385$ & $0.738 \pm 0.070$ & 3 & 0.007 & $0.676 \pm 0.069$ & 3 & 0.013 & $1.281 \pm 0.265$ & 6 & 0.021 \\
\hline+ BAPTA, $0 \mathrm{~mm} \mathrm{Ca}^{2+}$ & $0.870 \pm 0.026$ & 5 & $<0.001$ & $1.027 \pm 0.066$ & 3 & 0.001 & $0.937 \pm 0.039$ & 3 & 0.001 \\
\hline+ BAPTA, $2 \mathrm{~mm} \mathrm{Ca}^{2+}$ & $1.021 \pm 0.028$ & 7 & $<0.001$ & $1.022 \pm 0.073$ & 5 & $<0.001$ & $0.99 \pm 0.036$ & 4 & $<0.001$ \\
\hline$+\mathrm{THL}$ & $1.079 \pm 0.105$ & 5 & 0.003 & $0.962 \pm 0.073$ & 7 & 0.002 & $1.011 \pm 0.044$ & 6 & $<0.001$ \\
\hline + AM 251 & $0.519 \pm 0.051$ & 4 & 0.143 & $0.930 \pm 0.073$ & 5 & $<0.001$ & $1.309 \pm 0.380$ & 6 & 0.072 \\
\hline $\mathrm{CB}_{1} \mathrm{KO}$ & $1.038 \pm 0.043$ & 8 & $<0.001$ & $0.985 \pm 0.035$ & 8 & $<0.001$ & $1.099 \pm 0.144$ & 3 & $<0.001$ \\
\hline
\end{tabular}

Data are expressed as mean \pm SEM. Student's paired $t$ test was used to evaluate the significant changes upon 10 or $50 \mu \mathrm{m}$ DHPG treatments (first two rows). In all other cases, independent-samples $t$ test was used for statistical comparison. The $p$ values are the results of the comparisons between the data obtained upon $50 \mu \mathrm{m}$ DHPG application in the absence and the presence of different drugs, or in the measurements conducted in slices prepared from wild-type or $\mathrm{CB}_{1}$ knock-out mice.

fully eliminated the spike timing-dependent and chemical forms of LTD, and both also required endocannabinoid signaling, based on genetic evidence. Because the $\mathrm{mGlu}_{5}$-specific agonist CHPG [(RS)-2-chloro-5-hydroxyphenylglycine]-induced LTD could also be eliminated by pharmacological blockade of $\mathrm{CB}_{1}$ receptors when recorded LTD with an extracellular electrode (Izumi and Zorumski, 2012), it is highly likely that the activity of this molecular cascade to produce 2-AG mobilization was not perturbed by potential dialysis of the intracellular milieu when recording in the whole-cell mode.

Thus, together with another form of autaptic LTD observed in hippocampal cultures (Kellogg et al., 2009), these observations clearly demonstrate that at least three forms of endocannabinoidmediated LTD are possible at hippocampal excitatory connections onto pyramidal neurons.

\section{Endocannabinoid-LTD in specific hippocampal interneuron types}

LTD of glutamatergic inputs onto hippocampal interneurons can also be triggered by several induction protocols (McMahon and Kauer, 1997; Laezza et al., 1999; Gibson et al., 2008; Nissen et al., 2010; Le Duigou et al., 2011; Edwards et al., 2012). When tested, LTD in cortical GABAergic interneurons was found to be insensitive to treatment with $\mathrm{CB}_{1}$ antagonists (Lu et al., 2007; Gibson et al., 2008; Le Duigou et al., 2011; Edwards et al., 2012), which was surprising, because synthetic cannabinoid ligands effectively suppress excitatory inputs onto hippocampal interneurons including fast-spiking basket cells (Gibson et al., 2008; Holderith et al., 2011). Here, we found that LTD could not be induced in hippocampal interneurons in the presence of the $\mathrm{CB}_{1}$ antagonist or in animals lacking $\mathrm{CB}_{1}$ receptors. In contrast, robust LTD was observed upon both induction protocols in three types of fast- 
spiking interneurons (basket, axo-axonic, and bistratified cells) in wild-type animals indicating that parvalbumin-containing interneurons are also able to control the weights of their glutamatergic inputs via endocannabinoid mobilization. Similar results were obtained from O-LM cells that represent a type of somatostatin/ mGlu $_{1 \mathrm{a}}$-expressing GABAergic cells innervating distal dendrites of pyramidal cells (Baude et al., 1993; McBain et al., 1994). Thus, the evidence presented here suggests that at least four types of interneurons undergo endocannabinoid-LTD.

The present results also highlight that 2-AG is the key endocannabinoid responsible for LTD in hippocampal interneurons. First, significant amounts of DGL- $\alpha$ mRNA were expressed not only in principal cells (Katona et al., 2006; Yoshida et al., 2006) but also in two populations of hippocampal interneurons. Second, DGL- $\alpha$ was found in a perisynaptic annulus around excitatory synapses, even in aspiny parvalbumin-positive dendrites, implicating that the molecular machinery for endocannabinoid synthesis is remarkably compartmentalized, as shown before in aspiny cerebellar stellate cells (Soler-Llavina and Sabatini, 2006). The perisynaptic distribution of DGL- $\alpha$ observed in hippocampal interneurons and pyramidal cells as well as throughout the CNS (Katona et al., 2006; Yoshida et al., 2006; Lafourcade et al., 2007; Uchigashima et al., 2007; Mátyás et al., 2008; Nyilas et al., 2009) represents its integration into a signalosome called the perisynaptic signaling machinery, which has the postulated function to translate the magnitude of presynaptic glutamatergic activity into a negative-feedback signal via perisynaptic group I mGlu activation, 2-AG mobilization, and presynaptic $\mathrm{CB}_{1}$ engagement (Katona and Freund, 2008). Indeed, we found that treatment with either MPEP or THL completely eliminated both forms of LTD in hippocampal interneurons, arguing for the functional operation of this signalosome in hippocampal interneurons. Collectively, these findings highlight that the molecular architecture for retrograde 2-AG signaling is qualitatively conserved across cell types and brain regions.

\section{Functional implications}

Despite this qualitative similarity, quantitative differences in the induction thresholds of endocannabinoid-LTD reported here suggest that different cell types may produce 2-AG during different network states. We found that a stronger stimulation protocol or higher concentrations of DHPG were necessary to induce LTD in interneurons compared with pyramidal cells in accordance with significantly lower levels of DGL- $\alpha$ in GABAergic cells. When excessive neuronal activity increases extracellular glutamate to sufficiently high levels for activation of perisynaptic group I mGlu receptors, 2-AG signaling at the network level limits the spread of this potentially pathological activity and protects against neuronal insult (Katona and Freund, 2008). Our results suggest that this circuit breaker function switches on earlier in pyramidal cells than in GABAergic interneurons, and thereby may serve a role to prevent or delay the switch from normal to a pathological activity state (Monory et al., 2006). As a consequence of these differences, there should be a time window when excitatory-excitatory connections are weakened, while excitatory-inhibitory interactions remain fully functional. During this period, an alteration in synaptic weights will enhance the dominance of synaptic inhibition in the network, which may help to reverse a high activity state to a lower one (Malva et al., 2003). However, when synaptic excitation onto interneurons also becomes suppressed, network behavior might more easily shift to the pathological range (Piet et al., 2011). Thus, cell type-specific regulation of retrograde 2-AG signaling may be a beneficial way to exploit this messenger system in a network state-dependent mode.

\section{References}

Alger BE, Kim J (2011) Supply and demand for endocannabinoids. Trends Neurosci 34:304-315.

Antal M, Eyre M, Finklea B, Nusser Z (2006) External tufted cells in the main olfactory bulb form two distinct subpopulations. Eur J Neurosci 24:1124-1136.

Banerjee A, Meredith RM, Rodríguez-Moreno A, Mierau SB, Auberson YP, Paulsen O (2009) Double dissociation of spike timing-dependent potentiation and depression by subunit-preferring NMDA receptor antagonists in mouse barrel cortex. Cereb Cortex 19:2959-2969.

Baude A, Nusser Z, Roberts JD, Mulvihill E, McIlhinney RA, Somogyi P (1993) The metabotropic glutamate receptor (mGluR1) is concentrated at perisynaptic membrane of neuronal subpopulations as detected by immunogold reaction. Neuron 11:771-787.

Bender VA, Bender KJ, Brasier DJ, Feldman DE (2006) Two coincidence detectors for spike timing-dependent plasticity in somatosensory cortex. J Neurosci 26:4166-4177.

Bisogno T, Howell F, Williams G, Minassi A, Cascio MG, Ligresti A, Matias I, Schiano-Moriello A, Paul P, Williams EJ, Gangadharan U, Hobbs C, Di Marzo V, Doherty P (2003) Cloning of the first snl-DAG lipases points to the spatial and temporal regulation of endocannabinoid signaling in the brain. J Cell Biol 163:463-468.

Buzsáki G (2010) Neural syntax: cell assemblies, synapsembles, and readers. Neuron 68:362-385.

Chevaleyre V, Castillo PE (2003) Heterosynaptic LTD of hippocampal GABAergic synapses: a novel role of endocannabinoids in regulating excitability. Neuron 38:461-472.

Collingridge GL, Peineau S, Howland JG, Wang YT (2010) Long-term depression in the CNS. Nat Rev Neurosci 11:459-473.

Crozier RA, Wang Y, Liu CH, Bear MF (2007) Deprivation-induced synaptic depression by distinct mechanisms in different layers of mouse visual cortex. Proc Natl Acad Sci U S A 104:1383-1388.

Debanne D, Gahwiler BH, Thompson SM (1994) Asynchronous pre- and postsynaptic activity induces associative long-term depression in area CA1 of the rat hippocampus in vitro. Proc Natl Acad Sci U S A 91:1148-1152.

Edwards JG, Gibson HE, Jensen T, Nugent F, Walther C, Blickenstaff J, Kauer JA (2012) A novel non-CB1/TRPV1 endocannabinoid-mediated mechanism depresses excitatory synapses on hippocampal CA1 interneurons. Hippocampus 22:209-221.

Feldman DE (2009) Synaptic mechanisms for plasticity in neocortex. Annu Rev Neurosci 32:33-55.

Feldman DE, Brecht M (2005) Map plasticity in somatosensory cortex. Science 310:810-815.

Freund TF, Buzsáki G (1996) Interneurons of the hippocampus. Hippocampus 6:345-470.

Gao Y, Vasilyev DV, Goncalves MB, Howell FV, Hobbs C, Reisenberg M, Shen R, Zhang MY, Strassle BW, Lu P, Mark L, Piesla MJ, Deng K, Kouranova EV, Ring RH, Whiteside GT, Bates B, Walsh FS, Williams G, Pangalos MN, et al. (2010) Loss of retrograde endocannabinoid signaling and reduced adult neurogenesis in diacylglycerol lipase knock-out mice. J Neurosci 30:2017-2024.

Gentet LJ, Avermann M, Matyas F, Staiger JF, Petersen CC (2010) Membrane potential dynamics of GABAergic neurons in the barrel cortex of behaving mice. Neuron 65:422-435.

Gerdeman GL, Ronesi J, Lovinger DM (2002) Postsynaptic endocannabinoid release is critical to long-term depression in the striatum. Nat Neurosci 5:446-451.

Gibson HE, Edwards JG, Page RS, Van Hook MJ, Kauer JA (2008) TRPV1 channels mediate long-term depression at synapses on hippocampal interneurons. Neuron 57:746-759.

Gulyás AI, Megías M, Emri Z, Freund TF (1999) Total number and ratio of excitatory and inhibitory synapses converging onto single interneurons of different types in the CA1 area of the rat hippocampus. J Neurosci 19:10082-10097.

Gulyás AI, Szabó GG, Ulbert I, Holderith N, Monyer H, Erdélyi F, Szabó G, Freund TF, Hájos N (2010) Parvalbumin-containing fast-spiking basket cells generate the field potential oscillations induced by cholinergic receptor activation in the hippocampus. J Neurosci 30:15134-15145. 
Hájos N, Freund TF (2002) Pharmacological separation of cannabinoid sensitive receptors on hippocampal excitatory and inhibitory fibers. Neuropharmacology 43:503-510.

Han J, Kesner P, Metna-Laurent M, Duan T, Xu L, Georges F, Koehl M, Abrous DN, Mendizabal-Zubiaga J, Grandes P, Liu Q, Bai G, Wang W, Xiong L, Ren W, Marsicano G, Zhang X (2012) Acute cannabinoids impair working memory through astroglial CB1 receptor modulation of hippocampal LTD. Cell 148:1039-1050.

Holderith N, Németh B, Papp OI, Veres JM, Nagy GA, Hájos N (2011) Cannabinoids attenuate hippocampal gamma oscillations by suppressing excitatory synaptic input onto CA3 pyramidal neurons and fast spiking basket cells. J Physiol 589:4921-4934.

Huber KM, Roder JC, Bear MF (2001) Chemical induction of mGluR5- and protein synthesis-dependent long-term depression in hippocampal area CA1. J Neurophysiol 86:321-325.

Isaacson JS, Scanziani M (2011) How inhibition shapes cortical activity. Neuron 72:231-243.

Izumi Y, Zorumski CF (2012) NMDA receptors, mGluR5, and endocannabinoids are involved in a cascade leading to hippocampal long-term depression. Neuropsychopharmacology 37:609-617.

Jung KM, Mangieri R, Stapleton C, Kim J, Fegley D, Wallace M, Mackie K, Piomelli D (2005) Stimulation of endocannabinoid formation in brain slice cultures through activation of group I metabotropic glutamate receptors. Mol Pharmacol 68:1196-1202.

Jung KM, Astarita G, Zhu C, Wallace M, Mackie K, Piomelli D (2007) A key role for diacylglycerol lipase-alpha in metabotropic glutamate receptordependent endocannabinoid mobilization. Mol Pharmacol 72:612-621.

Katona I, Freund TF (2008) Endocannabinoid signaling as a synaptic circuit breaker in neurological disease. Nat Med 14:923-930.

Katona I, Freund TF (2012) Multiple functions of endocannabinoid signaling in the brain. Annu Rev Neurosci 35:529-558.

Katona I, Urbán GM, Wallace M, Ledent C, Jung KM, Piomelli D, Mackie K, Freund TF (2006) Molecular composition of the endocannabinoid system at glutamatergic synapses. J Neurosci 26:5628-5637.

Kellogg R, Mackie K, Straiker A (2009) Cannabinoid $\mathrm{CB}_{1}$ receptordependent long-term depression in autaptic excitatory neurons. J Neurophysiol 102:1160-1171.

Kemp A, Manahan-Vaughan D (2007) Hippocampal long-term depression: master or minion in declarative memory processes? Trends Neurosci 30:111-118.

Kiss J, Görcs TJ, Kuhn R, Knöpfel T, Csáky A, Halász B (1996) Distribution of metabotropic glutamate receptor $1 \mathrm{a}$ in the rat hypothalamus: an immunocytochemical study using monoclonal and polyclonal antibody. Acta Biol Hung 47:221-237.

Klausberger T, Somogyi P (2008) Neuronal diversity and temporal dynamics: the unity of hippocampal circuit operations. Science 321:53-57.

Klausberger T, Magill PJ, Márton LF, Roberts JD, Cobden PM, Buzsáki G, Somogyi P (2003) Brain-state- and cell-type-specific firing of hippocampal interneurons in vivo. Nature 421:844-848.

Kullmann DM, Lamsa KP (2011) LTP and LTD in cortical GABAergic interneurons: emerging rules and roles. Neuropharmacology 60:712-719.

Laezza F, Doherty JJ, Dingledine R (1999) Long-term depression in hippocampal interneurons: joint requirement for pre- and postsynaptic events. Science 285:1411-1414.

Lafourcade M, Elezgarai I, Mato S, Bakiri Y, Grandes P, Manzoni OJ (2007) Molecular components and functions of the endocannabinoid system in mouse prefrontal cortex. PLoS One 2:e709.

Lanté F, Cavalier M, Cohen-Solal C, Guiramand J, Vignes M (2006) Developmental switch from LTD to LTP in low-frequency-induced plasticity. Hippocampus 16:981-989.

Le Duigou C, Holden T, Kullmann DM (2011) Short- and long-term depression at glutamatergic synapses on hippocampal interneurons by group I mGluR activation. Neuropharmacology 60:748-756.

Lu JT, Li CY, Zhao JP, Poo MM, Zhang XH (2007) Spike-timing-dependent plasticity of neocortical excitatory synapses on inhibitory interneurons depends on target cell type. J Neurosci 27:9711-9720.

Ludányi A, Hu SS, Yamazaki M, Tanimura A, Piomelli D, Watanabe M, Kano M, Sakimura K, Maglóczky Z, Mackie K, Freund TF, Katona I (2011) Complementary synaptic distribution of enzymes responsible for synthesis and inactivation of the endocannabinoid 2-arachidonoylglycerol in the human hippocampus. Neuroscience 174:50-63.

Lujan R, Nusser Z, Roberts JD, Shigemoto R, Somogyi P (1996) Perisynaptic location of metabotropic glutamate receptors mGluR1 and mGluR5 on dendrites and dendritic spines in the rat hippocampus. Eur J Neurosci 8:1488-1500.

Maccaferri G, McBain CJ (1996) The hyperpolarization-activated current $\left(I_{\mathrm{h}}\right)$ and its contribution to pacemaker activity in rat CA1 hippocampal stratum oriens-alveus interneurones. J Physiol 497:119-130.

Maccaferri G, Roberts JD, Szucs P, Cottingham CA, Somogyi P (2000) Cell surface domain specific postsynaptic currents evoked by identified GABAergic neurones in rat hippocampus in vitro. J Physiol 524:91-116.

Malva JO, Silva AP, Cunha RA (2003) Presynaptic modulation controlling neuronal excitability and epileptogenesis: role of kainate, adenosine and neuropeptide Y receptors. Neurochem Res 28:1501-1515.

Marsicano G, Wotjak CT, Azad SC, Bisogno T, Rammes G, Cascio MG, Hermann H, Tang J, Hofmann C, Zieglgänsberger W, Di Marzo V, Lutz B (2002) The endogenous cannabinoid system controls extinction of aversive memories. Nature 418:530-534.

Mátyás F, Urbán GM, Watanabe M, Mackie K, Zimmer A, Freund TF, Katona I (2008) Identification of the sites of 2-arachidonoylglycerol synthesis and action imply retrograde endocannabinoid signaling at both GABAergic and glutamatergic synapses in the ventral tegmental area. Neuropharmacology 54:95-107.

McBain CJ, DiChiara TJ, Kauer JA (1994) Activation of metabotropic glutamate receptors differentially affects two classes of hippocampal interneurons and potentiates excitatory synaptic transmission. J Neurosci 14:4433-4445.

McMahon LL, Kauer JA (1997) Hippocampal interneurons express a novel form of synaptic plasticity. Neuron 18:295-305.

Meyer AH, Katona I, Blatow M, Rozov A, Monyer H (2002) In vivo labeling of parvalbumin-positive interneurons and analysis of electrical coupling in identified neurons. J Neurosci 22:7055-7064.

Miles R, Tóth K, Gulyás AI, Hájos N, Freund TF (1996) Differences between somatic and dendritic inhibition in the hippocampus. Neuron 16:815-823.

Min R, Nevian T (2012) Astrocyte signaling controls spike timingdependent depression at neocortical synapses. Nat Neurosci 15:746-753.

Mizuseki K, Diba K, Pastalkova E, Buzsáki G (2011) Hippocampal CA1 pyramidal cells form functionally distinct sublayers. Nat Neurosci 14:1174-1181.

Monory K, Massa F, Egertová M, Eder M, Blaudzun H, Westenbroek R, Kelsch W, Jacob W, Marsch R, Ekker M, Long J, Rubenstein JL, Goebbels S, Nave KA, During M, Klugmann M, Wölfel B, Dodt HU, Zieglgänsberger W, Wotjak CT, et al. (2006) The endocannabinoid system controls key epileptogenic circuits in the hippocampus. Neuron 51:455-466.

Navarrete M, Araque A (2010) Endocannabinoids potentiate synaptic transmission through stimulation of astrocytes. Neuron 68:113-126.

Nevian T, Sakmann B (2006) Spine $\mathrm{Ca}^{2+}$ signaling in spike-timingdependent plasticity. J Neurosci 26:11001-11013.

Niehusmann P, Seifert G, Clark K, Atas HC, Herpfer I, Fiebich B, Bischofberger J, Normann C (2010) Coincidence detection and stress modulation of spike time-dependent long-term depression in the hippocampus. J Neurosci 30:6225-6235.

Nissen W, Szabo A, Somogyi J, Somogyi P, Lamsa KP (2010) Cell typespecific long-term plasticity at glutamatergic synapses onto hippocampal interneurons expressing either parvalbumin or $\mathrm{CB}_{1}$ cannabinoid receptor. J Neurosci 30:1337-1347.

Nosyreva ED, Huber KM (2005) Developmental switch in synaptic mechanisms of hippocampal metabotropic glutamate receptor-dependent longterm depression. J Neurosci 25:2992-3001.

Nyilas R, Gregg LC, Mackie K, Watanabe M, Zimmer A, Hohmann AG, Katona I (2009) Molecular architecture of endocannabinoid signaling at nociceptive synapses mediating analgesia. Eur J Neurosci 29:1964-1978.

Ohno-Shosaku T, Tsubokawa H, Mizushima I, Yoneda N, Zimmer A, Kano M (2002) Presynaptic cannabinoid sensitivity is a major determinant of depolarization-induced retrograde suppression at hippocampal synapses. J Neurosci 22:3864-3872.

Ouimet CC, Katona I, Allen P, Freund TF, Greengard P (2004) Cellular and subcellular distribution of spinophilin, a PP1 regulatory protein that bundles F-actin in dendritic spines. J Comp Neurol 479:374-388.

Palmer MJ, Irving AJ, Seabrook GR, Jane DE, Collingridge GL (1997) The group I mGlu receptor agonist DHPG induces a novel form of LTD in the CA1 region of the hippocampus. Neuropharmacology 36:1517-1532.

Piet R, Garenne A, Farrugia F, Le Masson G, Marsicano G, Chavis P, Manzoni 
OJ (2011) State-dependent, bidirectional modulation of neural network activity by endocannabinoids. J Neurosci 31:16591-16596.

Robbe D, Kopf M, Remaury A, Bockaert J, Manzoni OJ (2002) Endogenous cannabinoids mediate long-term synaptic depression in the nucleus accumbens. Proc Natl Acad Sci U S A 99:8384-8388.

Rodríguez-Moreno A, Paulsen O (2008) Spike timing-dependent longterm depression requires presynaptic NMDA receptors. Nat Neurosci 11:744-745.

Rouach N, Nicoll RA (2003) Endocannabinoids contribute to short-term but not long-term mGluR-induced depression in the hippocampus. Eur J Neurosci 18:1017-1020.

Silberberg G, Grillner S, LeBeau FE, Maex R, Markram H (2005) Synaptic pathways in neural microcircuits. Trends Neurosci 28:541-551.

Sjöström PJ, Turrigiano GG, Nelson SB (2003) Neocortical LTD via coincident activation of presynaptic NMDA and cannabinoid receptors. Neuron 39:641-654.

Soler-Llavina GJ, Sabatini BL (2006) Synapse-specific plasticity and compartmentalized signaling in cerebellar stellate cells. Nat Neurosci 9:798-806.

Tanimura A, Yamazaki M, Hashimotodani Y, Uchigashima M, Kawata S, Abe M, Kita Y, Hashimoto K, Shimizu T, Watanabe M, Sakimura K, Kano M (2010) The endocannabinoid 2-arachidonoylglycerol produced by diacylglycerol lipase alpha mediates retrograde suppression of synaptic transmission. Neuron 65:320-327.

Uchigashima M, Narushima M, Fukaya M, Katona I, Kano M, Watanabe M (2007) Subcellular arrangement of molecules for 2-arachidonoylglycerolmediated retrograde signaling and its physiological contribution to synaptic modulation in the striatum. J Neurosci 27:3663-3676.

Uchigashima M, Yamazaki M, Yamasaki M, Tanimura A, Sakimura K, Kano
M, Watanabe M (2011) Molecular and morphological configuration for 2-arachidonoylglycerol-mediated retrograde signaling at mossy cellgranule cell synapses in the dentate gyrus. J Neurosci 31:7700-7714.

Varga C, Lee SY, Soltesz I (2010) Target-selective GABAergic control of entorhinal cortex output. Nat Neurosci 13:822-824.

Xu JY, Chen R, Zhang J, Chen C (2010) Endocannabinoids differentially modulate synaptic plasticity in rat hippocampal CA1 pyramidal neurons. PLoS One 5:e10306.

Yasuda H, Huang Y, Tsumoto T (2008) Regulation of excitability and plasticity by endocannabinoids and PKA in developing hippocampus. Proc Natl Acad Sci U S A 105:3106-3111.

Yoshida T, Fukaya M, Uchigashima M, Miura E, Kamiya H, Kano M, Watanabe M (2006) Localization of diacylglycerol lipase- $\alpha$ around postsynaptic spine suggests close proximity between production site of an endocannabinoid, 2-arachidonoyl-glycerol, and presynaptic cannabinoid $\mathrm{CB}_{1}$ receptor. J Neurosci 26:4740-4751.

Yoshino H, Miyamae T, Hansen G, Zambrowicz B, Flynn M, Pedicord D, Blat Y, Westphal RS, Zaczek R, Lewis DA, Gonzalez-Burgos G (2011) Postsynaptic diacylglycerol lipase mediates retrograde endocannabinoid suppression of inhibition in mouse prefrontal cortex. J Physiol 589:4857-4884.

Zemankovics R, Káli S, Paulsen O, Freund TF, Hájos N (2010) Differences in subthreshold resonance of hippocampal pyramidal cells and interneurons: the role of h-current and passive membrane characteristics. J Physiol 588:2109-2132.

Zimmer A, Zimmer AM, Hohmann AG, Herkenham M, Bonner TI (1999) Increased mortality, hypoactivity, and hypoalgesia in cannabinoid $\mathrm{CB}_{1}$ receptor knockout mice. Proc Natl Acad Sci U S A 96:5780-5785. 